\title{
MICROPROPAGAÇÃO DE BANANEIRA DOS CULTIVARES MAÇÃ E GRANDE NAINE VISANDO PRODUÇÃO DE MUDAS DE BAIXO CUSTO
}

\section{ANA PAULA PENTEADO MARTINS SENDIN}

Engenheira Agrônoma

Orientador: Prof. Dr. AUGUSTO TULMANN NETO

Dissertação apresentada à Escola Superior de Agricultura "Luiz de Queiroz", Universidade de São Paulo, para obtenção do título de Mestre em Agronomia, Área de Concentração: Genética e Melhoramento de Plantas.

PIRACICABA

Estado de São Paulo - Brasil

Junho -2001 
ERRATA

ANA PAULA PENTEADO MARTINS SENDIN. Micropropagação de bananeira dos cultivares Maçã e Grande Naine visando produção de mudas de baixo custo

\begin{tabular}{|c|c|c|c|c|}
\hline p. & item & linha & onde se lê & leia-se \\
\hline $\mathrm{xi}$ & Resumo & sétima & menores custo & menores custos \\
\hline xii & Resumo & segunda & $\begin{array}{l}\text {.. foi menor do que } \\
\text { em sala de } \\
\text { crescimentoida.. } \\
\text { têm expectativa }\end{array}$ & tinham expectativa \\
\hline 7 & $\begin{array}{l}2.2 .3 \\
2.2 .3\end{array}$ & $\begin{array}{l}\text { vigésima } \\
\text { segunda } \\
\text { décima } \\
\text { segunda }\end{array}$ & $\begin{array}{l}\text { reproduz-se } \\
\text { partes sombreadas }\end{array}$ & $\begin{array}{l}\text { propaga-se } \\
\text { partes iluminadas }\end{array}$ \\
\hline 16 & 2.6 & quarta & patógenos & patógenos e pragas \\
\hline 29 & 3.1 & $\begin{array}{l}\text { décima } \\
\text { nona }\end{array}$ & ..são a nível.. & ..são ao nível.. \\
\hline 61 & Tabela 4 & $\begin{array}{l}\text { décima } \\
\text { nona }\end{array}$ & total 85 & total \\
\hline
\end{tabular}




\title{
Dados Internacionais de Catalogação na Publicação (CIP) DIVISÃO DE BIBLIOTECA E DOCUMENTAÇĀO - Campus "Luiz de Oueiroz"/USP
}

\author{
Sendin, Ana Paula Penteado Martins \\ Micropropagação de bananeira dos cultivares maça e Grande Naine visando \\ produção de mudas de baixo custo / Ana Paula Penfeado Martins Sendin. - - Piracicaba, \\ 2001. \\ $72 \mathrm{p}$. \\ Dissertação (mestrado) - - Escola Superior de Agricultura Luiz de Queiroz, 2001. \\ Bibliografia. \\ 1. Banana 2. Melhoramento genético vegetal 3. Muda 4. Propagação "in vitro" 5. \\ Variedade I. Título
}

CDD 634.772 


\section{Agradeço,}

Ao Deus criador,

Por me guiar e acompanhar em tudo que faço

\section{Ofereço,}

Aos Meus Pais e irmã

Esdras, Ruth e Flóvia

Pela Compreensão e Amor

Dedico,

Ao Meu amado Esposo

Tércio

Pelo incentivo a perseguir meus ideais

“Entrega o teu caminho ao Senhor, confia n'Ele e o mais Ele fará" (Salmos 37:5) 


\section{AGRADECIMENTOS}

A Deus, pela vida e sabedoria para chegar até aqui.

Aos meus familiares, pelo carinho, pelo incentivo e pela compreensão nos momentos de ausência.

À Escola Superior de Agricultura "Luiz de Queiroz" - ESALQ/USP, pela oportunidade concedida.

Ao Centro de Energia Nuclear na Agricultura - CENA/USP, pelo auxílio na realização do trabalho.

Ao Prof. Dr. Augusto Tulmann Neto, orientador, pelos ensinamentos, pela amizade e dedicação na organização deste trabalho.

Aos Técnicos Benedita Inês F.P. Rodrigues, Paulo Cassieri Neto, Wlamir A. Godoy e José Benedito Alves pela ajuda fundamental na realização deste trabalho.

Às bibliotecárias, Marília R.G. Henyei e Raquel Cristina T. de Carvalho, pela ajuda nas Referências Bibliográficas.

À Coordenação de Aperfeiçoamento de Pessoal de Nível Superior (CAPES), pelo apoio financeiro ao trabalho, através da bolsa concedida.

Aos colegas do curso de pós-graduação, pelo convívio, companheirismo e troca de conhecimentos.

Ao Daniel do Amaral Gurgel Penteado, pelo auxílio técnico.

À Professora Clarice Garcia Borges Demétrio e ao Silvano César Costa, Doutorando do Departamento de Ciências Exatas da ESALQ/USP, pelo valioso auxílio nas análises estatísticas, pelo apoio.

À Gláucia Anti pelos acertos, pelo companheirismo, pela amizade. 
A todos aqueles que se fizeram presentes no meu dia-a-dia, e de alguma forma contribuíram para a realização deste trabalho. 


\section{SUMÁRIO}

Página

RESUMO

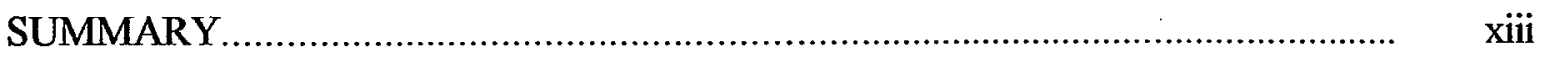

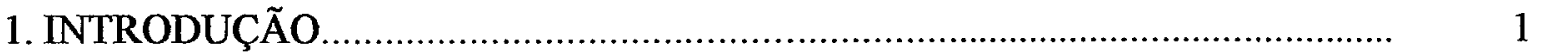

2.REVISÃO DE LITERATURA …….......................................................... 5

2.1 Utilizações da banana .................................................................................. 5

2.2 Características Gerais das Bananeiras Cultivadas ............................................... 6

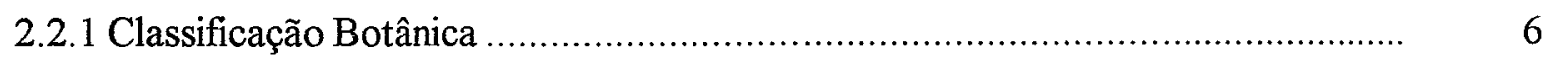

2.2.2 Principais cultivares, origem, evolução e níveis cromossômicos..................... 6

2.2.3 Distribuição Geográfica ..............................................................................

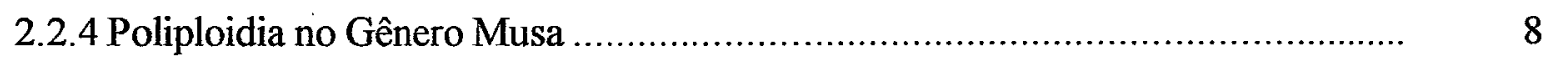

2.3 Melhoramento Genético da Bananeira ......................................................... 9

2.4 Melhoramento por meio de mutações espôntaneas ou induzidas ........................ 11

2.5 Hibridação Somática ..................................................................................... 15

2.6 Micropropagação na Cultura da Bananeira ..................................................... 15

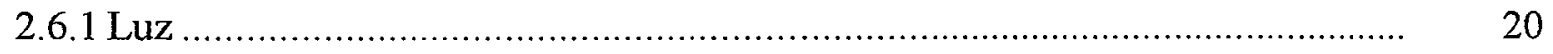

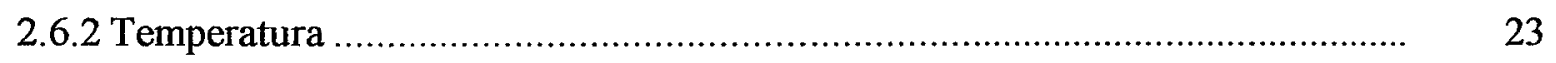

2.7 Variação Somaclonal em Bananeira .............................................................. 24

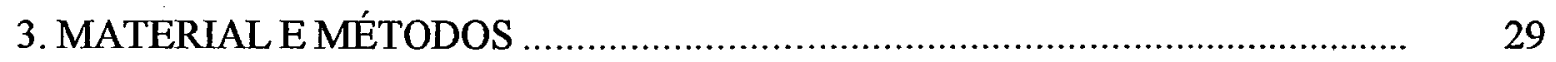

3.1 Material Vegetal, Obtenção de Explantes e Micropropagação ........................... 29

3.2 Produção de Mudas de Bananeira Micropropagadas .......................................... 30

3.3 Micropropagação em diferentes condições ambientais e épocas dos anos de

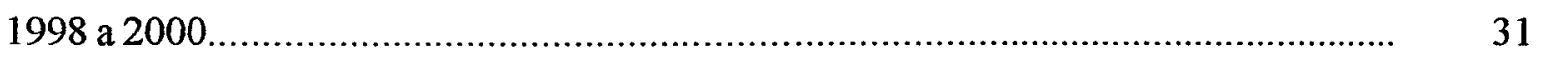

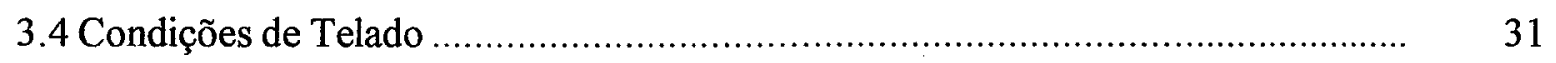

3.5 Condições de Sala deCrescimento ................................................................ 32

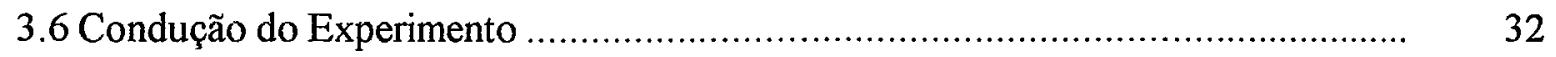

3.7 Levantamento de produtos, serviços para posterior cálculo de custos de mudas

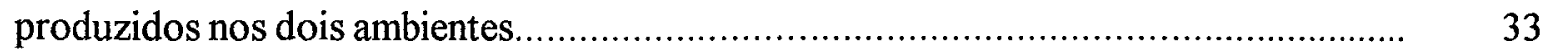

3.8. Delineamento Experimental .................................................................... 33 


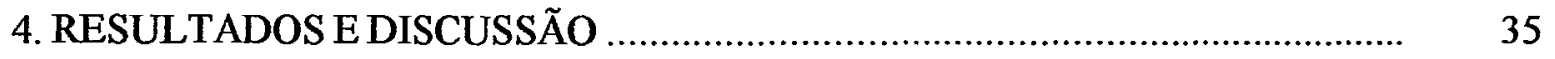

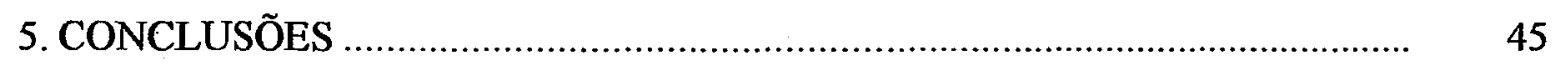

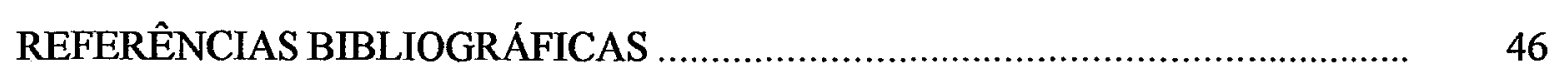

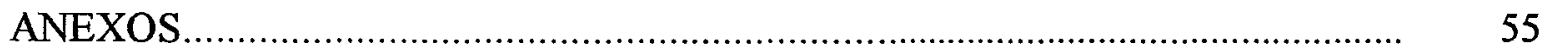




\section{LISTA DE QUADROS}

Página

1 Tipos de equipamentos, fornecedores com respectivo Modelo/Marca, usados no laboratório de produção de mudas de banana micropropagadas......................

2 Preço (US\$ $\$ 1000 \mathrm{~g}$ ) de Produtos Químicos para confecção de meios utilizados 1 multiplicação e enraizamento de mudas micropropagadas de banana Maçã Grande Naine

3 Número utilizado de aparelhos elétricos e lâmpadas para sala de crescimento de mudas micropropagadas.

4 Componentes, materiais elétricos e mão-de-obra necessários para implantação de uma sala de crescimento e um telado 


\section{LISTA DE TABRLAS}

Página

1 Dados referentes à temperatura, luminosidade e umidade relativa da sala de crescimento

2 Dados referentes à temperatura, luminosidade e umidade relativa do telado nas épocas 1,2 e 3

3 Número de brotações na época 1, em três repicagens do cultivar banana Maçã, mantido em condições de sala de crescimento.

4 Número de brotações na época 1 , em três repicagens do cultivar banana Maçã, mantido em condições de telado.

5 Número de brotações na época 1, em três repicagens do cultivar banana Grande Naine, mantido em condições de sala de crescimento

6 Número de brotações na época 1, em três repicagens do cultivar banana Grande Naine, mantido em condições de telado.

7 Número de brotações na época 2, em três repicagens do cultivar banana Maçã, mantido em condições de sala de crescimento

8 Número de brotações na época 2, em três repicagens do cultivar banana Maçã, mantido em condições de telado.

9 Número de brotações na época 2, em três repicagens do cultivar banana Grande Naine, mantido em condições de sala de crescimento.

10 Número de brotações na época 2 , em três repicagens do cultivar banana Grande Naine, mantido em condições de telado.

11 Número de brotações na época 3, em três repicagens do cultivar banana Maçã, mantido em condições de sala de crescimento.

12 Número de brotações na época 3, em três repicagens do cultivar banana Maçã, mantido em condições de telado.

13 Número de brotações na época 3, em três repicagens do cultivar banana Grande Naine, mantido em condições de sala de crescimento 
14 Número de brotações na época 3 , em três repicagens do cultivar banana Grande Naine, mantido em condições de telado.

15 Dados referentes aos tipos de Tratamentos: Sala de crescimento (Tratamento 1) e Telado (Tratamento 2); Número de Observações; Média do número de brotos; Desvio padrão e Valores Mínimos e Máximos obtidos, para o cultivar Grande Naine

16 Dados referentes às três diferentes épocas: Número de Observações; Média do número de brotos; Desvio padrão e Valores Máximos e Mínimos para o cultivar Grande Naine......

17 Estimativa de Parâmetros para o cultivar Grande Naine.

18 Análise Estatística TIPO 3 para o cultivar Grande Naine.

19 Tratamentos, Número de Observações, Média do número de brotos, Desvio Padrão e Valores Mínimos e Máximos obtidos para o cultivar Maçã.

20 Etapas, Número de Observações, Média do número de brotos, Desvio Padrão e Valores Máximos e Mínimos para o cultivar Maçã.

21 Estimativa de Parâmetros para o cultivar Maçã

22 Análise Estatística TIPO 3 para o cultivar Maçã.

23 Tipos de equipamentos, fornecedores com respectivos Modelo/Marca e preços, usados no laboratório de produção de mudas de banana micropropagadas.

24 Custos de Produtos Químicos para confecção de meios utilizados 1 multiplicação e enraizamento de mudas micropropagadas de banana Maçã Grande Naine.

25 Custos com energia elétrica utilizada na micropropagação de mudas de banana Maçã e Grande Naine em sala de crescimento.

26 Custos de energia elétrica em forno de microondas e na autoclave, utilizados na preparação de meios de cultura em sala de crescimento e em telado.

27 Custo final de mudas ( $R$ \$) micropropagadas de banana Maçã e Grande Naine, produzidas em sala de crescimento e em telado nas três épocas da realização do experimento 
28 Custo em reais de implementação de sala de crescimento de $8 \mathrm{~m}^{2}$ utilizada na micropropagação de mudas de banana Maçã e Grande Naine ...............................

29 Custo de implementação de telado utilizado na micropropagação de mudas de banana Maçã e Grande Naine. 


\title{
MICROPROPAGAÇÃO DE BANANEIRA DOS CULTIVARES MAÇÃ G GRANDE NAINE VISANDO PRODUÇÃO DE MUDAS DE BAIXO CUSTO
}

\author{
Autor: ANA PAULA PENTEADO MARTINS SENDIN
}

Orientador: Prof. Dr. AUGUSTO TULMANN NETO

\section{RESUMO}

Objetivou-se desenvolver método que permitisse a obtenção de mudas de bananeira micropropagadas de baixo custo. Utilizaram-se as cultivares de bananeira Maçã e Grande Naine, analisando-se os custos de produção de mudas durante três épocas dos anos de 1998 a 2000, em dois ambientes distintos. Um dos ambientes foi a sala de crescimento, normalmente usada para micropropagação, com controle de iluminação e temperatura e o outro um telado sem tais controles, com iluminação e temperatura ambientes e com instalações mais simples e de menores custo. Foram efetuados os cálculos dos custos das mudas micropropagadas obtidas nos dois ambientes, levando-se em conta os seguintes fatores: total de mudas produzidas nas três épocas; produtos químicos usados para confecção de meios de cultura para multiplicação e enraizamento; energia elétrica. Calculou-se também o custo para implementação de sala de crescimento e telado, semelhantes aos usados nessa pesquisa. Concluiu-se que para os dois cultivares houve redução de custo das mudas produzidas em condição de telado. Atribuiu-se esse menor custo principalmente devido ao fato que em telado não se 
necessita de energia elétrica, que é usada na iluminação e refrigeração da sala de crescimento. $\mathrm{O}$ custo de implementação de um telado é bem menor do que uma sala de crescimento. Tanto em condição de sala de crescimento como em telado o número de mudas produzidas nos dois cultivares foi menor do que em sala de crescimentoidas mas para os dois cultivares a redução de custo de produção em telado foi próxima $(81,1 \%$ para banana Grande Naine e 85,4\% para banana Maçã). Entretanto, o menor número de mudas produzidas em telado pode exigir um espaço físico relativamente maior para a produção de um certo número de mudas necessário para plantio em época determinada e isto precisa ser considerado quando da aplicação desse método. 


\title{
BANANA MICROPROPAGATION, MAÇÃ AND GRAND NAINE CULTIVARS, AIMING LOW COST PLANTLET
}

\author{
Author: ANA PAULA PENTEADO MARTINS SENDIN
}

Adviser: Prof. Dr. AUGUSTO TULMANN NETO

\section{SUMMARY}

The present work was carried out to establish the methodology to obtain plantlets of banana at low cost through micropropagation. The cultivars Maçã and Grand Naine were utilized, analyzing multiplication rates and production cost of plantlets during different three periods fro 1998 to 2000 in to distinct environments: one was growth room, normally used for micropropagation where temperature and light are controlled and another was screened house which is a simple and low cost structure with environmental light and temperature. The cost of plantlets obtained in these two environments was calculated considering the following factors: total plantlets obtained in three periods in a year, costs of chemical products used to prepare media for multiplication and rooting and of electricity consumption. The costs of installation of temperature and light controlled growth room and screened house, similar to those used in the present work, were also calculated. It was concluded that production cost of plantlets of these two banana cultivars was lower in screened house than in growth room, which is attributed principally to no consumption of electricity that is higher in growth room to control both light and temperature. The cost of installation of screened house is much lower than that of growth room. The number of 
plantlets of the cultivar Grand Naine obtained both in growth room and screened house was higher than that of Maçã, although the reduction of production cos of plantlets in screened house of the both cultivars was almost the same $(81,1 \%$ for Grand Naine and $85,4 \%$ for Maçã). However, reduced number of plantlets produced in screened house can require relatively large physical space in order to supply them which are necessary to plant in a determined period. This should be taken in consideration when this methodology is applied. 


\section{INTRODUÇÃo}

A banana (Musa spp.) é uma das frutas tropicais de maior importância econômica. As importações mundiais têm expectativa de crescimento na ordem de 3,6\% ao ano, e de 10,6 milhões de toneladas em 1995 para 12,22 milhões de toneladas em 1999.

A banana (Musa spp.) é uma das frutas mais consumidas no mundo, sendo explorada na maioria dos países tropicais. De toda produção mundial, da ordem de 44 milhões de toneladas anuais, o Brasil responde por cerca de $17 \%$ (7,5 milhões de toneladas). A despeito do volume de produção, a participação do Brasil, no mercado internacional é mínima ( $1 \%$ das transações), enquanto o Equador se faz presente com $20 \%$ do total (FNP Consultoria e Comércio, 1998).

É cultivada em todos os estados da Federação, desde a faixa litorânea até os planaltos do interior, contudo há restrições devido a fatores climáticos, como temperatura e precipitação.

Ocupa o segundo lugar dentre as fruteiras em relação à área colhida, sendo cultivada em 520.014 ha. É também uma das frutas preferidas pelos consumidores, sendo superada apenas pela laranja. $\mathrm{O}$ volume total de produção, é praticamente todo consumido dentro do país. Quanto à distribuição regional da produção, tem-se: Nordeste $(34,4 \%)$, Sudeste $27,8 \%$ Norte (18,3\%), Sul (11,5\%) e Centro-Oeste (7,9\%). Em relação aos estados maiores produtores, encontram-se: Bahia (16\%), São Paulo (11\%), Santa Catarina $(9 \%)$, Pará $(9 \%)$, Pernambuco $(9 \%)$, Minas Gerais $(8 \%)$, ficando os demais estados com o restante da produção (FNP Consultoria e Comércio, 1998).

A bananicultura brasileira apresenta características peculiares que a diferenciam das principais regiões produtoras no mundo, tanto em relação à diversidade climática em 
que é explorada, quanto a cultivares, forma de comercialização e exigência de mercado consumidor. Os cultivos são geralmente tradicionais, com baixos índices de capitalização e níveis tecnológicos. A produtividade média está em torno de $15 \mathrm{t} / \mathrm{ha}$ contra 70 t/ha do Equador, Colômbia e nações da América Central. Esses países recebem cobertura e assistência de especialistas de firmas importadoras ou de grandes companhias estrangeiras do setor de frutas, afim de que forneçam produtos nos padrões exigidos pelos consumidores. Parte dessas empresas passará a investir no Brasil e poderá modificar, aqui também o panorama da fruticultura. Cultivos tecnificados são encontrados em São Paulo, Santa Catarina, Goiás e Minas Gerais, nos quais observam muitas vezes a utilização de tecnologias geradas e/ou adaptadas de outros países. A utilização de novos conceitos e os investimentos em tecnologia na formação dos bananais no estado de São Paulo fez com que este passasse a colher 1 milhão de toneladas de banana por ano, equivalendo essa quantidade a quase $15 \%$ da produção nacional (FNP Consultoria e Comércio, 1998).

Dentre os fatores que contribuem com a baixa produtividade no país pode-se citar: baixa performance dos cultivares em uso, o porte elevado de alguns cultivares, a falta de tolerância a seca, a pragas e doenças (Dantas et al., 1993), como também aspectos relacionados a interesses políticos, sociais e econômicos. Vale frisar que se considera a falta de cuidados na colheita e no processamento como o maior entrave à melhoria da qualidade. É generalizada a falta de conhecimento e informação por parte dos produtores e de outros agentes no que diz respeito a: 1) regiões mais propícias à instalação da cultura; 2) seu desenvolvimento e necessidades, especialmente na condução dos cachos; 3) comercialização do produto ajustado as necessidades e exigências do mercado consumidor, 4) preços nos diferentes centros de comercialização (FNP Consultoria e Comércio, 1998).

Assim, pode-se dizer que o atraso tecnológico no tratamento pós-colheita, a baixa qualidade do produto e a desorganização comercial fizeram com que o Brasil perdesse espaço na comercialização externa. Sua participação no mercado internacional é mínima, sendo que a exportação restringe-se praticamente à Argentina e Urł̣guai, e em virtude de problemas de qualidade no produto nacional, registram-se, aindà que em 
pequenas quantidades, importações do Chile, Equador e Estados Unidos. Prevê-se que o mercado internacional, representado principalmente pela Europa, Extremo Oriente e América Latina, demandará para este final de século mais de 12 milhões de toneladas, com um crescimento de 3,6 \% ao ano (FNP Consultoria e Comércio, 1998).

Portanto, em função do seu enorme potencial, a bananicultura vem despertando um interesse crescente entre os pesquisadores de todo o mundo. Porém, o inventário de conhecimentos científicos e tecnológicos sobre a mesma é ainda relativamente pequeno, havendo muitos problemas básicos que impedem o seu desenvolvimento e aproveitamento em maior escala.

São bem conhecidas as vantagens e limitações do uso de técnicas da cultura de tecidos no melhoramento de plantas. Quando o uso de técnicas de cultura de tecidos é aplicado,por exemplo em indução de mutações, o melhorista tem que preparar milhares de explantes. Em países em desenvolvimento, isto constitui uma séria limitação, pois os custos envolvidos no manejo dessas grandes populações são altos (Kodym, 1999). Outro fator relevante em tais países, seria o espaço limitado de salas de crescimento com condições artificiais de luz e temperatura. Assim sendo, métodos que possam diminuir os custos e permitir o crescimento destes materiais em condições mais naturais (iluminação natural - uso de telados de sombrite e ausência de refrigeração - fora das salas com controle de muitos itens e com ar condicionado disponível) ou dispor-se de meios de cultura com composição mais barata, serão de grande importância, principalmente para países como o Brasil, em franca expansão e irão aumentar o uso de técnicas de cultura de tecidos. Sabe-se ainda que há falta de dados publicados nesta linha, para esta cultura.

Também se tem conhecimento que a cultura da banana tem grande importância para o país e as vantagens que mudas micropropagadas podem trazer para os agricultores, daí então se resolver realizar este experimento que faz parte do conjunto de pesquisas que o Laboratório de Melhoramento de Plantas do CENA/USP vem desenvolvendo.

Em virtude do que foi exposto anteriormente, este trabalho objetivou usar a cultura da bananeira como modelo visando a produção de mudas micropropagadas de 
baixo custo, comparando-se a taxa de brotação em dois ambientes diferentes e em três épocas do ano. 


\section{REVISÃO DE LITERATURA}

\subsection{Utilizações da banana}

Consumida na quase totalidade na forma in natura, a banana constitui parte integrante da alimentação das populações de baixa renda, não só pelo seu alto valor nutritivo, como pelo seu baixo custo, cabendo-lhe um papel fundamental na fixação da mão de obra rural. Aproximadamente $90 \%$ das bananas produzidas são utilizadas como alimento para consumo doméstico (Silva, 1998). O consumo per capita anual é altamente variável entre os países, sendo que os países da África constituem os maiores consumidores mundiais (FAO, 1995), e o Brasil ocupa a sétima posição com uma taxa de 30,28 Kg per capita/ano, superando o SriLanka, Canadá e USA.

Como alimento as bananas são altamente ricas em carboidratos (cerca de $35 \%$ ) e fibras (6-7\%). Os frutos são importantes fontes de elementos minerais e vitaminas, tais como: potássio, magnésio, cálcio fósforo, sódio, ferro e vitaminas $\mathrm{A}, \mathrm{B}$ e $\mathrm{C}$, sendo que uma única banana supre cerca de um quarto da quantidade diária de vitamina $\mathrm{C}$ recomendada para crianças. Além disso, não contém colesterol e o conteúdo de açúcar é maior que o da maçã.

Apesar de apenas os frutos serem utilizados como fonte de alimento, praticamente todas as partes da planta podem ser aproveitadas para este ou outros fins. Dentre as diversas utilizações, pode-se citar (FAO, 1995): produção alcoólica, alimentação animal, uso medicinal, fonte de fibras entre outros. 


\subsection{Características gerais das bananeiras cultivadas}

\subsubsection{Classificação botânica}

Conforme a sistemática de classificação hierárquica proposta por Champion (1967), as bananeiras produtoras de frutos comestíveis pertencem a:

Classe: Monocotiledônea

Ordem: Scitaminales

Familia: Musaceae

Subfamília: Musoideae

Gênero: $M$ usa

Secção: AustraliMusa

Callimusa

Rhodochlamys

(Eu-)Musa

Cheesman (1948), propôs uma classificação para o gênero Musa aceita atualmente no mundo todo, a qual baseia-se no número básico de cromossomos. Esta se divide em dois grupos:

- espécies com $n=10$ cromossomos pertencem às secções AustraliMusa e CalliMusa

- espécies com n $=11$ cromossomos integram as secções Rhodoclamys e (Eu-)Musa, as quais apresentam potencialidade como germoplasma útil para melhoramento genético das variedades cultivadas. Segundo Shepherd (1990), essas espécies são:

Seç̧ão Rhodoclamys: Musa ornata Roxburgh, M. Velutina Wendl \& Drude, M. lateria Cheesman, M. rubra e $M$. sanguinea;

Secção (Eu-)Musa: M. acuminata Colla, M. flaviflora Simmonds, $M$. ochracea Shepherd, M. schizocarpa Simmonds, M. halabanensis e M. balbisiana Colla.

\subsubsection{Principais Cultivares, origem , evolução e níveis cromossômicos}

A evolução da maioria dos cultivares de banana ocorreu no Continente 
Asiático, a partir de duas espécies diplóides selvagens, a saber: $M$. Acuminata Colla e $M$. balbisiana Colla, cujas variedades apresentam niveis cromossômicos, di, tri ou tetraplóides, com 22,33, ou $44(\mathrm{n}=\mathrm{x}=11)$, em combinações variadas denominadas pelas letras A (M. acuminata) e B (M. balbisiana), de cujas combinações resultam os grupos $\mathrm{AA}, \mathrm{BB}, \mathrm{AB}, \mathrm{AAA}, \mathrm{AAB}, \mathrm{ABB}, \mathrm{AAAA}, \mathrm{AAAB}, \mathrm{ABBB}$ (Silva et al., 1998).

Embora exista um número expressivo de variedades de banana no Brasil, quando se consideram aspectos como preferência dos consumidores, produtividade, tolerância a pragas e doenças, resistência à seca, porte e resistência ao frio, restam poucos cultivares com potencial agronômico para serem usados comercialmente. Os cultivares mais difundidos no Brasil são: Prata, Pacovan, Prata Anã, Maçã, Terra e D’Angola, do grupo AAB, e Nanica ; Nanicão e Grande Naine, do grupo AAA, utilizadas principalmente na exportação.

\subsubsection{Distribuição Geográfica}

A bananeira é uma planta tipicamente tropiçal, considerada um vegetal herbáceo completo, pois compreende raiz, caule, folhas, flores, frutos e eventualmente sementes, sendo o caule representado pelo rizoma, exigindo calor constante e elevada umidade para o seu bom desenvolvimento. Essas condições favoráveis são registradas na faixa compreendida entre os paralelos $30^{\circ}$ de latitude norte e sul, nas regiões onde as temperaturas se situam entre os limites de $10^{\circ} \mathrm{C}$ a $40^{\circ} \mathrm{C}$. Entretanto, existe a possibilidade de seu cultivo em latitudes acima de $30^{\circ}$, desde que a temperatura seja adequada. Devido à sua ampla adaptação, é cultivada em quase todos os países tropicais (Moreira, 1987).

Reproduz-se normalmente por via vegetativa, emitindo novos brotos ou rebentos no decorrer do seu desenvolvimento, formando um conjunto de bananeiras interligadas em diversos estádios de desenvolvimento, chamado de "touceira". O último estádio de desenvolvimento de uma bananeira, em uma touceira, é a fase de florescimento e frutificação. Após o amadurecimento de seus frutos, verifica-se em seguida o secamento de todas as folhas da bananeira, completando seu ciclo na touceira (Moreira, 1987). 
Em condições subtropicais, o potencial de crescimento das plantas é sazonalmente limitado e a média mínima mensal de temperatura do ar no inverno, pode baixar de $17^{\circ} \mathrm{C}$ a $9^{\circ} \mathrm{C}$, ou até mais. Essas baixas temperaturas podem acarretar em efeitos drásticos nas bananas como: redução na sua razão de crescimento, suas folhas amarelecerem e as plantas apresentarem distúrbios fisiológicos como menores taxas de fotossintese, transpiração e condutância estomatal. As baixas temperaturas durante o desenvolvimento dos frutos, também afetam a diferenciação celular e resultam na deformação dos mesmos. Um longo tempo de exposição das folhas ao frio e à baixa intensidade luminosa, resulta em destruição fotooxidativa de clorofila. A fotoinibição pode ser detectada visualmente em banana comparando-se a coloração de folhas expostas ao sol com as folhas mantidas na sombra. Onde ocorre a fotooxidação da clorofila, as folhas têm aparência amarelecida, enquanto que as partes sombreadas da lâmina permanecem verdes (Damasco et al., 1997).

Desde 1960, plantações de Gros Michel foram replantadas com cultivares do subgrupo Cavendish, desde então, as bananas para exportação são deste grupo.

\subsubsection{Poliploidia no Gênero $M u s a$}

O processo evolutivo da maioria das plantas superiores teve como principal contribuinte o aumento básico de cromossomos da espécie. Esse aumento provocado pela poliploidia foi freqüentemente favorável permitindo uma melhor adaptação das espécies ao seu ambiente. Como conseqüência, aproximadamente metade das plantas cultivadas é poliplóide, possuindo números de cromossomos que são múltiplos exatos do conjunto básico característico das espécies.

A poliploidia, muitas vezes, é fator de esterilidade parcial ou completa. $\mathrm{Na}$ cultura da bananeira ela desempenhou um importante papel, visto que as cultivares comerciais sem sementes são triplóides, com 33 cromossomos, enquanto que as bananeiras selvagens, seminiferas apresentam $2 n=22$ cromossomos. A reduzida capacidade de produção de sementes nos triplóides, decorrente da esterilidade gamética ocasionada por: 
- problemas de pareamento gerados pela triploidia do tecido germinativo;

- irregularidades ou atraso no crescimento de tubos polínicos nos estilos de flores femininas;

- não-fertilização, mesmo com o desenvolvimento do tubo, por razões desconhecidas, permitiu a utilização comercial destes cultivares, uma vez que as sementes de Musa são duras, o que torna seus frutos comercialmente inaceitáveis (Dantas et al., 1993).

Além disso, a poliploidia está diretamente associada ao alto vigor das plantas de Musa spp. pois as variedades triplóides e tetraplóides são bem mais vigorosas que as diplóides. Observou-se ainda que as plantas poliplóides apresentavam folhas mais inclinadas e sistema radicular mais fraco quando comparadas com as diplóides.

Os estudos genéticos dos poliplóides propiciaram uma série de informações. Wilson (1946) examinou a meiose de alguns clones triplóides de Musa e mediante as análises citológicas verificou que a supressão da primeira divisão meiótica conduz à formação de gametas triplóides que podem se combinar com gametas haplóides de indivíduos diplóides, dando origem a genótipos tetraplóides. Este comportamento citológico está completamente de acordo com o processo evolutivo das bananeiras.

\subsection{Melhoramento Genético da Bananeira}

As primeiras tentativas de melhoramento genético de bananeira visando produtividade e resistência a doenças mediante hibridações ocorreram no final da década de 20, em Honduras, Trinidad e Jamaica, motivadas pela murcha de Fusarium (Shepherd, 1992). No início da década de 30 foi sintetizado o primeiro tetraplóide a partir do cruzamento de uma cultivar triplóide (AAA - Gros Michel) com um diplóide (AA - selvagem). Desta forma, iniciou-se um sistema de hibridação que permite o melhoramento de alguns cultivares triplóides de banana e também de diplóides (AA), para síntese posterior de tetraplóides, o qual continua sendo universalmente usado com resultados satisfatórios (Dantas et al., 1999).

No melhoramento de bananeira o papel do germoplasma AA é o de contribuir 
com resistências às diversas doenças e com outras características favoráveis.

O pré-requisito básico dos programas de pesquisa objetivando produzir novos cultivares tem sido a formação, caracterização e avaliação de amplas coleções de germoplasma. $\mathrm{Na}$ utilização deste germoplasma, o aumento da variabilidade desejada ou a eliminação de variabilidade indesejada são etapas de real importância no esquema do melhoramento genético pretendido. De modo que quando essa variabilidade é bem adequada ao trabalho do melhorista, não há justificativa para proceder à indução de mutações (Soares Filho, 1990; Dantas et al., 1999).

A produção de banana é inteiramente dependente de clones não melhorados que foram selecionados na natureza, domesticados e mantidos em cultivo. As mutações espontâneas têm contribuído para a ampliação da limitada diversidade genética em $M u s a$ (Novak, 1992). A poliploidia e a esterilidade são fatores que dificultam o melhoramento dos cultivares de Musa. Os métodos tradicionais de melhoramento de plantas apresentam certas dificuldades, o que gera um grande potencial para a biotecnologia nesta cultura (Domingues et al., 1994).

Existe uma série de problemas que ainda precisam ser resolvidos no melhoramento da bananeira, dentre os quais destaca-se susceptibilidade a doenças como mal-do-panamá. Alguns cultivares de interesse comercial chegam a ter produção nômade para escapar da presença do patógeno. É o caso das bananas do grupo AAB, ao qual pertence a cultivar Maçã, de grande aceitação no território brasileiro.

Um programa de melhoramento tem por objetivo desenvolver bananas resistentes a pragas e doenças, com porte e ciclo reduzido, como também produtivas, mediante mutações, hibridação somática e cruzamentos de diplóides (AA) melhorados com triplóides comerciais, avaliando e selecionando as variedades tetraplóides superiores em diferentes regiões produtoras do país (Dantas et al; 1999). A obtenção de novos cultivares de bananeira, mais produtivas, resistentes a doenças e pragas, e com porte adequado, não basta para determinar o sucesso em termo de adoção pelos bananicultores. A substituição de uma cultivar, é dificil, pois a banana é uma fruta de consumidor exigente em sabor, além disso, o melhoramento genético depara com outras dificuldades, como a ausência de sementes nos cultivares comerciais, em razão da 
inexistência de pólen viável, ou talvez, de polinizadores naturais eficientes (Silva, 1998).

O aumento do consumo mundial, com a abertura de novos mercados e a exigência dos consumidores, está indicando um novo rumo a ser tomado pela bananicultura. Vem se tornando fundamental na busca de novas áreas de plantio e na renovação de áreas pouco produtivas, a introdução de material propagativo de bananeira com qualidade genética e sanidade incontestáveis. Tecnicamente, uma das alternativas recomendáveis seria a utilização de mudas obtidas in vitro, isenta de patógenos.

Portanto a micropropagação vem se destacando como uma das técnicas mais importantes e está assumindo uma posição de destaque em diversos países do mundo, principalmente Europa Ocidental e Estados Unidos (Fornasieri, 1998).

\subsection{Melhoramento por meio de mutações espontâneas ou induzidas}

As culturas de propagação vegetativa, dentre elas a bananeira, são usualmente heterozigotas, e este fato, aliado às dificuldades de aplicação dos métodos tradicionais de melhoramento, e do grande número de mutantes espontâneos cultivados comercialmente, sugere que o uso de mutagênicos possa trazer resultados de interesse. A indução de mutação visa a alteração de uma ou poucas características de cultivares bem estabelecidas, mas sem alterar suas características desejáveis, e pode ser particularmente importante para espécies estéreis de Musa onde não existe reprodução sexual que possa gerar variabilidade genética (Domingues et al., 1994).

De maneira geral, as perspectivas de melhoramento por mutações são limitadas, embora seja claro que as mutações tenham ocupado um lugar importante na diversificação de clones de bananeira, principalmente na formação dos subgrupos, contribuindo para um aumento significativo na variabilidade útil disponível (Simmonds, 1973).

Uma das mutações mais importantes é a que provoca o nanismo ou seminanismo, permitindo uma maior densidade de plantio e facilidade de execução de práticas culturais. Essa mutação tem ocorrido principalmente nos seguintes subgrupos 
e cultivares triplóides:

- grupo AAA subgrupo Cavendish, subgrupo Gros Michel e 'Caru Roxa' grupo AAB 'Maçã' e subgrupo Terra;

-grupo ABB - subgrupo Figo e 'Pisang Awak'. A 'Prata Anã' também parece ser uma mutação semi-anã, porém não é mutação da 'Prata' (Shepherd et al., 1984), e sim de um genótipo de porte alto ainda não definido. As mutações anãs de 'Caru Roxa', 'Maçã ' e 'Figo' são conhecidas no Caribe, não obstante considera-se que em geral estas formas anãs têm sido pouco aproveitadas, sendo que só recentemente pôde-se avaliar a 'Figo Anã'.

Outra mutação importante no Brasil modificou o tamanho do fruto: a 'Pacovan ' tem maiores frutos que a 'Prata' típica, tanto no comprimento quanto no diâmetro. A parte vegetativa e a inflorescência masculina da 'Pacovan' são idênticas às da 'Prata' comum. Outra mutação semelhante existente no subgrupo Prata é exemplificada pela 'Pacha Nadan', da Índia. Com relação à resistência a doenças, vale ressaltar que essa característica quase não tem sido modificada pelas mutações espontâneas.

Alguns tipos de bananeira têm sido muito mais mutáveis que outros. O tipo que apresenta a maior freqüência de mutações é o subgrupo Terra. Na África Ocidental e Equatorial foram identificados mais de 50 fenótipos diferentes. Dois exemplos do outro extremo, ou seja, de cultivares pouco mutáveis, são a 'Mysore' amplamente cultivada na Índia, e a 'Maçã', apesar da existência de mutação anã.

Quando o melhoramento de uma cultivar justificar a procura de mutações, a indução destas e o isolamento de setores mutantes sempre apresentarão melhores perspectivas que a busca de mutações espontâneas nos bananais. Embora ainda sejam pouco avaliadas em bananeira, as técnicas para a indução de mutações, seja por meio de mutagênicos fisicos (radiações) ou pela aplicação de mutagênicos químicos, devem aumentar tanto a diversidade quanto a taxa de variações somáticas, possibilitando inclusive a recuperação de características úteis, não detectadas dentre os mutantes espontâneos.

Os obstáculos ao desenvolvimento dessas técnicas têm-se relacionado à dificuldade de obtenção de material de bananeira apropriado para tratamento, e à 
dificuldade de recuperação de mutantes sólidos.

A indução de mutação aliada à técnica de cultura in vitro, é um sistema efetivo no melhoramento de cultivares modernos, num curto período de tempo, especialmente em culturas de propagação vegetativa. Tais plantas compreendem um grupo de grande importância econômica. Fatores como alta heterozigose, ciclo longo, esterilidade, e outros, dificultam o melhoramento em muitas dessas espécies. A mutagênese e a seleção in vitro podem contribuir como técnicas auxiliares de importância para estas plantas (Ancora et al., 1982; Constantin, 1984; Donini \& Micke, 1984).

Iniciaram-se estudos, na cultura da bananeira (Espino et al., 1986; Novak et al., 1986) com uso de radiações em brotos apicais. Doses de 1 a $20 \mathrm{Krad}$ de raios gama foram utilizadas para tratamentos in vitro, posteriormente, foram feitas multiplicações das novas plantas obtidas em função do quimerismo que ocorre após a irradiação. Em seguida as plantas obtidas poderão ser inoculadas com o agente causal, se o objetivo principal for resistência à doença, ou então observadas em condições de campo, em busca de mutantes para outras características agronômicas. Como resultado do trabalho iniciado por Novak (1986), foi obtido o mutante denominado "FATOM-1", com maior precocidade e alta produção, o qual, após ensaios tradicionais, foi liberado para o cultivo na Malásia (Tan et al., 1993).

Também Novak \& Brunner, (1992) isolaram ápices caulinares de banana e plátanos economicamente importantes e micropropagaram em tubos de ensaio. Vários tipos de irradiação (raios gama, nêutrons) foram aplicados em ápices, os quais resultaram em plantas. Esta pesquisa mais uma vez resultou no desenvolvimento de clones mutantes do mais importante cultivar de banana de mesa, Grande Naine. Estas variedades estão sendo testadas em vários países para observar-se a performance em campo, qualidade do fruto e precocidade.

Quanto à indução de mutação em ápices caulinares de banana sob cultivo in vitro, estudos preliminares estão sendo conduzidos na Áustria, Tailândia, Filipinas e Cuba. Foram utilizados raios gama em todos os casos sendo o primeiro objetivo determinar a dosagem ótima dessa radiação. $\mathrm{Na}$ Áustria, vários experimentos estão em execução no sentido de desenvolver uma metodologia que permita, ainda nas culturas 
in vitro, a identificação e seleção de ápices caulinares resistentes a sigatoka negra.

A técnica do cultivo in vitro de ápices caulinares de bananeira, assim como de outras espécies, oferece a possibilidade de obter plantas mutantes (Torres, 1990), tornando possível à seleção in vitro de variedades tolerantes a ambientes desfavoráveis, como presença de cloreto de alumínio no solo (Matsumoto, 1991). Para alguns autores, o uso de mutantes induzidos ou espontâneos parece ser uma alternativa do melhoramento das bananeiras tipo Cavendish, já que, em função da esterilidade total que apresentam, não parecem passíveis à aplicação de técnicas convencionais (Souza et al., 1997).

Também tem sido utilizado esse tipo de cultivo de ápices caulinares in vitro, como sistema auxiliar aos métodos de melhoramento, pois se trata de uma estrutura multicelular, e a ocorrência de mutação somática leva ao quimerismo, e, portanto, a irradiação sobre ápices caulinares deve ser seguida de um avanço de gerações antes do início da seleção, para que possa haver uma ampliação no setor mutado (Domingues et al., 1994).

Broertjes \& Harten (1988) comentam que células submetidas à irradiação e que sofreram danos fisiológicos ou cromossômicos apresentam menor capacidade mitótica em relação às células que não sofreram estes efeitos.

Em trabalhos envolvendo indução de mutação, utilizam-se freqüentemente, doses próximas à $\mathrm{LD}_{50} \mathrm{e} / \mathrm{ou}$ à $\mathrm{GR}_{50}$ (dose ou concentração do mutagênico responsável pela redução de $50 \%$ na sobrevivência e no crescimento dos explantes tratados, respectivamente).

Domingues et al.,(1994) avaliaram os efeitos de doses de raios gama em ápices caulinares de bananeira desenvolvidos in vitro para indução de mutação. Os ápices foram tratados com raios gama nas doses de 20,40,60,80 e 100 Gy e subcultivados por 4 ciclos vegetativos e concluiu-se pelas variegações foliares que este é o número mínimo de gerações a ser utilizado antes da seleção de mutantes. A dose de $40 \mathrm{~Gy}$, resultou em maior aumento de frequência de variantes $(13,49 \%)$ em comparação com o controle $(0,85 \%)$. Não foram observadas plantas resistentes ao fungo, após inoculação com o agente causal do mal-do-panamá. 
A indução de mutação utilizando-se do agente químico etilmetanosulfonato (EMS), em banana foi adaptada na Embrapa. Foram selecionadas in vitro plantas mutantes tolerantes as toxinas do fungo causador do mal-do-Panamá. Dez destes mutantes estão sendo avaliados em Cruz das Almas-BA (Dantas et al., 1999).

Pelos trabalhos citados, observa-se a importância que pode ter a técnica de cultura de tecidos, quando associada à indução de mutações no melhoramento de plantas.

\subsection{Hibridação Somática}

As técnicas de cultivo de células e protoplastos possibilitam a realização de hibridações somáticas, transformação genética e a seleção de variantes somaclonais.

A hibridação somática compreende basicamente o isolamento de protoplastos, fusão de protoplastos, regeneração e avaliação dos híbridos resultantes.

$\mathrm{Na}$ Embrapa, foram estabelecidas células em suspensão a partir de ápices meristemáticos de banana Maçã, obtendo-se protoplastos, os quais foram cultivados com a técnica de "nurse culture", com células de arroz. Com alta eficiência foram produzidos embriões somáticos e plântulas in vitro. Em adição foram realizadas também fusões elétricas desses protoplastos. Atualmente os esforços têm se concentrado na regeneração de plantas a partir dos embriões obtidos com a fusão de protoplastos. Posteriormente será realizada a análise de DNA das plantas regeneradas para a identificação dos híbridos, estudando-se em seguida os caracteres agronômicos dos híbridos produzidos (Dantas et al., 1999).

\subsection{Micropropagação na Cultura da Bananeira}

A micropropagação, é a propagação das plantas in vitro, e apresenta muitas vantagens sobre a propagação convencional e sua participação na agricultura, está se expandindo. Entretanto, seu uso comercial ainda é limitado, isto, por causa do alto custo de produção resultando principalmente em altos custos laboratoriais e baixa taxa de 
crescimento in vitro e pouca porcentagem de sobreviventes durante a aclimatação (Kozai et al., 1997). A meta da micropropagação é uma produção massal de indivíduos geneticamente idênticos, fisiologicamente uniformes, com desenvolvimento normal e plantas livres de patógenos, que podem ser aclimatadas num reduzido período de tempo e com baixo custo de produção (Kozai et al., 1997)/O desenvolvimento de sistemas automatizados de controle do meio ambiente e o melhoramento dos sistemas de cultivo in vitro, são essenciais para uma redução significativa nos custos de produção (AitkenChristie et al., 1995).

$\mathrm{Na}$ busca de novas áreas de plantio e na renovação de áreas pouco produtivas são fundamentais a introdução de mudas de bananeira com alta qualidade, que podem ser obtidas através da técnica de micropropagação in vitro. A muda micropropagada pode estar isenta de qualquer tipo de virose como o CMV - cucumber mosaic virus e o BUNCH TOP, nematóide como o Rhadopholus similis e consequentemente favorecer uma vida útil mais longa de um bananal comercial (Kricorian, 1989; Banerjee \& De Langhe, 1985).

A micropropagação in vitro por meio da cultura de meristema tem sido relatada em muitas espécies de plantas, tanto monocotiledôneas quanto dicotiledôneas. É observada uma taxa diferencial de multiplicação, e alta, entre espécies do mesmo gênero ou quando cultivadas sob mesmas condições.

A produção comercial de mudas de bananeira por meio da cultura in vitro de ápices caulinares tem sido empregada com sucesso em países como Israel, Costa Rica, Cuba, Austrália e Taiwan, possibilitando a produção de mudas superiores e praticamente livres de pragas e doenças, como mal-do-Panamá, moko, nematóides e broca do rizoma. Segundo Kricorian \& Cronauer (1986), o desenvolvimento dessas técnicas é importante, por permitir a rápida multiplicação de novos clones de cultivares selecionados e híbridos, obtidos a partir de programas de melhoramento genético. As mudas micropropagadas produzem $30 \%$ mais do que mudas obtidas convencionalmente (Sanada, 1993), e permitem uma colheita sincronizada nos primeiros ciclos da cultura graças à homogeneidade das mudas, possibilitam um maior vigor das plantas, maior número de dedos por penca, maior número de pencas por cacho, menor variabilidade no 
tamanho e forma dos frutos, e menor incidência de nematóides em áreas contaminadas (Oliveira, 1997).

As principais vantagens das plantas micropropagadas referem-se à uniformidade, isenção de patógenos e possibilidade de multiplicar milhões de mudas de clones elites em pequeno espaço fisico e curto período de tempo. As limitações relacionam a possibilidade de ocorrência de variações somaclonais, proliferação de viroses nos casos de ausência de indexação de matrizes e, principalmente, ao alto custo de produção das mudas. Este último fator tem sido o maior empecilho à expansão do setor no país.

Outras vantagens proporcionadas pela correta aplicação desta técnica estão relacionadas com a possibilidade de produzir uma quantidade muito grande de mudas em curto espaço de tempo na época em que interessar ao agricultor, possibilitando também a introdução rápida de variedades novas de interesse comercial (Kricorian \& Cronauer, 1984).

O uso de propagação in vitro contribui para redução de custos de cultivo e também podem obter as plantas em períodos em que os preços estejam em alta. Então, o desenvolvimento desta técnica tem recebido considerável atenção durante os últimos 15 anos, quando foi estabelecida. As mudas micropropagadas, quando comparadas com as convencionais, são capazes de apresentar performance igual ou superior. Em geral, se estabelecem mais rapidamente, crescem mais vigorosamente, são mais altas, tem menores e mais uniformes períodos de produção. Os ganhos em campo usando esse tipo de muda, foram de $0 \%$ para $23 \%$ (Vuylsteke et al., 1997).

As técnicas de micropropagação são atualmente aquelas de maior impacto da biotecnologia e vem assumindo posição destacada em culturas tropicais (Souza et al., 1997).

A partir do cultivo efetuado dos primeiros ápices caulinares por Ma \& Smii (1972), citados por Hwang \& Ko (1987), a micropropagação da bananeira tomou grande impulso, e nos últimos 20 anos vem sendo incrementada, visando algumas aplicações: multiplicação rápida de variedades, eliminação de doenças, conservação de germoplasma, intercâmbio de germoplasma e seleção in vitro (Souza et al., 1997).

São vários os fatores que oneram a produção de mudas, através da 
micropropagação, e um dos maiores é a mão-de-obra, respondendo por $40 \%$ a até $70 \%$ do custo. Têm sido conduzidos estudos visando o desenvolvimento de sistemas automatizados ou semi-automatizados de produção. Nos últimos anos foram produzidos equipamentos sofisticados para o preparo, esterilização e distribuição semi-automática de meio de cultura e robôs para a repicagem dos explantes. No início da década de 90 foi proposto um novo sistema para multiplicação in vitro de plantas: a imersão temporal (RITAS). Poucos anos mais tarde, pesquisadores cubanos adaptaram equipamentos simples para a produção de mudas em escala comercial por esse sistema (Oliveira, 1996). O desenvolvimento do sistema de controle de meios automático e o melhoramento do sistema de cultivo in vitro, são essenciais para uma redução significativa nos custos de produção (Aitken-Christie et al., 1995). Recentemente, extensivas pesquisas e o progresso, têm enfocado a automação e a robotização nos processos de micropropagação. Entretanto, pesquisa dos efeitos e fatores de controle ambiental in vitro tem sido limitada, vasos convencionais são pequenos e sem ar, dificultando o controle e as medidas de fatores do meio de cultivo (Kozai et al., 1997).

Algumas das principais vantagens desse sistema, refere-se à obtenção de taxas maiores de multiplicação e menores de contaminação microbiana, além de proporcionar uma redução significativa nas necessidades de mão-de-obra, melhoramento da nutrição das plantas devido o contato direto durante a imersão. Comparando com culturas desenvolvidas em meio semi-sólido, no desenvolvimento e germinação de embriões somáticos, cada RITA, pode produzir 700-1000 plantas e a razão de proliferação de meristemas em 20 dias pode ser 2,5 vezes maior.

Também, buscando reduzir os custos de produção e multiplicação de bananas, um método simples, que se baseia no uso de um meio composto de água comum e açúcar doméstico como fonte de carbono. Os brotos cresceram e apresentaram múltipla brotação (4-5 brotos /cultivo). Maior enraizamento e crescimento dos brotos, foi observado em solução de sal denominada Knop's $\left(250 \mathrm{mgL}^{-1} \mathrm{KNO}_{3}, 1000 \mathrm{mgL}^{-1}\right.$ $\mathrm{Ca}\left(\mathrm{NO}_{3}\right)_{2}, 250 \mathrm{mgL}^{-1}, \mathrm{MgSO}_{4} .7 \mathrm{H}_{2} \mathrm{O}, 250 \mathrm{mgL}^{-1} \mathrm{KH}_{2} \mathrm{PO}_{4}$ ) suplementado com NAA, conduzidos sob condições controladas de luz, temperatura e umidade relativa.

Em alguns laboratórios de cultura de tecido, as condições de crescimento são 
consideradas muito críticas para o sucesso do programa de melhoramento. Muitos cientistas têm feito uso de químicos altamente purificados e sofisticadas facilidades fisicas para aumentar a eficiência das técnicas de cultura in vitro, pois a cultura de tecidos é custosa, seja na manutenção ou na implementação das técnicas, e os laboratórios não tem como manter tais programas pela limitação econômica.

Alguns fatores da micropropagação da bananeira ainda são limitantes para o pleno sucesso da técnica, mas estudos desenvolvidos procuram contornar estas limitações. Estes fatores são: contaminação das culturas; escurecimento dos explantes e variação somaclonal (Souza et al., 1997).

Recentemente, extensivas pesquisas em desenvolvimento têm enfocado a automatização e a robotização dos processos de micropropagação (Aitken-Christie et al., 1995). Entretanto, pesquisas sobre o efeito e controle dos fatores do ambiente in vitro têm sido limitadas. $\mathrm{O}$ ambiente in vitro é controlado para atingir diferentes objetivos tanto para a qualidade quanto para a produção econômica (controle do crescimento e desenvolvimento, controle de características morfológicas e fisiológicas e redução no consumo de energia). $\mathrm{O}$ ambiente fisico in vitro é um sistema convencional de cultura de tecidos que é completamente diferente de uma casa de vegetação e freqüentemente os resultados fisiológicos são indesejáveis e há problemas patológicos (Kozai et al., 1997).

O meio convencional in vitro é caracterizado por Aitken-Christie et al., 1995 como tendo: alta umidade relativa, temperatura constante, baixa densidade fotossintética, larga flutuação de concentração de $\mathrm{CO}_{2}$, alta concentração de açúcares e sais, substâncias reguladoras, acúmulo de substâncias tóxicas e ausência de microorganismos. Sabe-se que o controle do microambiente promove o crescimento e desenvolvimento das plantas, reduz desordens morfológicas e fisiológicas e encoraja o crescimento e desenvolvimento mais rápido e vigoroso das plantas durante o estágio de aclimatação (Jeong et al., 1995). Isto é esperado para reduzir significativamente os custos de produção.

Alguns fatores afetam o crescimento das plantas in vitro, como: temperatura, luminosidade, radiação, composição atmosférica de gases e movimentação do ar. Segundo Kodym et al., 1999 para aumentar-se à eficiência das técnicas in vitro, a cultura 
de tecidos tem se sofisticado com facilidades fisicas como: temperatura, umidade, condições de iluminação e aeração, que estão se padronizando e sendo controladas.

\subsubsection{Luz}

As plantas estão sujeitas a vários estímulos ambientais, e considera-se a luz um dos mais importantes estímulos para vários fenômenos fisiológicos, bem como para a fotossíntese e mudanças morfológicas (Kamada et al., 1995).

$\mathrm{O}$ termo luz é freqüentemente definido como radiação eletromagnética perceptível ao olho humano (comprimento: $380-760 \mathrm{~nm}$ ). Entretanto, no campo fisico, refere-se a radiação eletromagnética do ultravioleta $(10-380 \mathrm{~nm})$ ao infravermelho (760nm-1mm). No caso de plantas, o termo luz deverá ser definido como radiação eletromagnética a qual causa reações fotoquímicas nas plantas.

As plantas utilizam a energia luminosa para realizar a fotossíntese e são estimuladas a otimizar sua captação e sincronização do desenvolvimento com as variações sazonais durante o seu ciclo de vida (Souza, 1998). A luz influencia também a germinação de algumas sementes, a indução floral e a taxa de florescimento (Souza, 1998), o crescimento celular, a formação de brotações adventícias in vitro (Kamada et al., 1995) o movimento dos estômatoś' e a biossíntese de compostos fenólicos. Recentemente, tem-se constatado influência da luz nas sinteses de óleos essenciais de plantas medicinais e aromáticas (Li \& Deng; 1996).

A qualidade espectral, a intensidade e a duração do período luminoso podem influenciar separadamente o metabolismo e o desenvolvimento da planta. A intensidade e a qualidade da luz determinam a velocidade do crescimento celular, a acumulação de pigmentos e a diferenciação dos plastídios (Souza, 1998).

Em diversas espécies, o efeito da luz pode apresentar diferentes efeitos sobre órgãos ou tipos de células e sobre células vizinhas. A luz influencia diretamente a taxa de divisão celular e a duração da divisão, sendo o tamanho final das células totalmente influenciado pela luz (Souza, 1997). Os órgãos também respondem diferentemente a luz, pois o crescimento de tecidos foliares, hipocótilo e caule são 
influenciados pela quantidade e qualidade da radiação. $O$ aumento da radiação luminosa incrementa a atividade fotossintética, aumentando também a produção de hidratos de carbono e teor de matéria seca, enquanto a deficiência luminosa proporciona alongamento celular, causando estiolamento sem alteração do teor de matéria seca (Souza, 1998).

Em plantas de hibiscos sob $840 \mu \mathrm{mol} \cdot \mathrm{m}^{-2} \cdot \mathrm{s}^{-1}$ houve redução no tempo de florescimento e aumento no número de flores, enquanto plantas sob $420 \mu \mathrm{mol} . \mathrm{m}^{-2} \mathrm{~s}^{-1}$ apresentaram maior altura e folhagens de coloração verde escura e aspecto viçoso (Neumaier \& Blessington, 1987).

Já Takagi, \& Qu, 1995 afirmam que a qualidade da luz e o fotoperíodo são bem conhecidos pela influência no crescimento e desenvolvimento de muitas plantas. Entretanto, há poucas pesquisas sobre estes efeitos no cultivo das plantas in vitro.

Também Miyashita et al., 1995 acreditam que a qualidade da luz tem uma influência significativa no crescimento, morfologia e diferenciação das plantas in vitro e ex vitro. Luz de comprimento vermelho e vermelho longo, afetam a elongação das plantas in vitro. Os efeitos das radiações azuis e UV na inibição do crescimento celular e da elongação de brotos in vitro são atribuídos ao sistema de percepção de luz presente nos tecidos das plantas (Souza, 1998). O controle do crescimento e da morfologia por modificação da qualidade de luz, é uma importante técnica na cultura de tecidos de plantas.

As luzes fluorescentes brancas (PPFD) são as fontes mais utilizadas na micropropagação, elas dão uniformidade horizontal sobre toda área iluminada. Há uma diferença de iluminação (PPFD) dentro e fora de uma cultura em frascos, que é dependente do frasco, e do tipo de fechamento que ele apresenta. A fonte de luz é instalada acima dos frascos e as plantas recebem então, a iluminação. $O$ nível de PPFD, o período de claro/escuro, a diferença de temperatura e suas interações influenciam no crescimento e desenvolvimento das plantas in vitro (Kozai et al, 1997). A simples alteração do ambiente por uma mudança na posição da fonte de luz da lateral por sobre as plantas de batata, pode aumentar ambos, tanto $o$ crescimento quanto $o$ 
desenvolvimento morfológico in vitro (Hayashi et al., 1992).

Segundo Kodym et al., 1999, as lâmpadas fluorescentes são usadas para cultura de tecidos e são citadas por $90 \%$ das pesquisas literárias como a fonte de luz usada. Os custos de iluminação perfazem $65 \%$ do total da conta de eletricidade e é um dos mais altos custos não laboratoriais. Além disso, a luz natural tem sido usada por muitos laboratórios nas salas de crescimento, só que isto não poderá ser aceito amplamente até que os efeitos dela, tornem-se bem compreendidos e sua aplicação se demonstre experimentalmente. Alguns autores não recomendam o uso de luz natural, mesmo sendo econômica, devido às flutuações radicais e a dificuldade de controle.

As lâmpadas fluorescentes comumente usadas em muitas culturas, emitem radiação subótima, a qual é baixa em comprimento de onda de vermelho intenso.

Para o controle da fotomorfogênese das plantas, diferentes tipos de diodos (LED), que emitem luz podem ser usados para emitir comprimentos azul, vermelho ou vermelho longo, a baixo custo. A aplicação de LED no crescimento das plantas seria uma alternativa prática no sistema de iluminação convencional (Kozai et al., 1997).

Luz emitindo diodo (LED), gera luz monocromática. LEDs são amplamente usadas como luz de sinais, luzes indicadoras em painéis e quadros de aviso, mas raramente usadas em cultura de tecidos. Segundo Tenessen et al, citado por Myiashita et al.,1995 o autor sugere que as LEDs podem apresentar igual intensidade de luz comparada com a luz solar emitida na superficie, e tem muitas vantagens sobre as fontes de luz convencionais nas pesquisas de fotossíntese. As LEDs vermelhas podem ser usadas com aplicação prática na micropropagação, devido ao seu alto rendimento de fótons e seu baixo preço comparado com LEDs de outras cores (Miyashita et al., 1995).

Parâmetros importantes de crescimento e desenvolvimento das culturas quanto ao microambiente de iluminação estão ligados na densidade de fluxo de luz, distribuição espectral, ciclo de iluminação e direção da luminosidade. Estes dois últimos têm somente recentemente se tornado objeto de interesse (Aitken-Christie, 1995). Têm sido conduzidos muitos estudos dos efeitos da densidade do fluxo de luz no crescimento e desenvolvimento de culturas. Em alguns estudos, irradiação [W.m $\left.{ }^{-2}\right]$ ou iluminação 
[lx] tem sido empregadas como unidades de densidade de fluxo de luz.

A tecnologia da cultura de tecidos tem se desenvolvido utilizando-se baixas intensidades de luz (15-65 $\mu$ mols $\left.\mathrm{m}^{-2} \mathrm{~s}^{-1}\right)$. Lee e Wetzstein (1988) citados por Souza (1998) encontraram que níveis excedentes de luz $315 \mu \mathrm{mols} \mathrm{m}^{-2} \mathrm{~s}^{-1}$ induzem clorose foliar em Liquidambar sp. Exposição a altas PPFD pode induzir fotoinibição e dano fotooxidativo no dispositivo fotossintético e é agravado por fatores adicionais de estresse, como baixos níveis de $\mathrm{CO}_{2}$, e altas temperaturas. Entretanto, efeitos benéficos de altos níveis de luz no crescimento e desenvolvimento de brotos in vitro têm sido demonstrados sob condições de enriquecimento de $\mathrm{CO}_{2}$ em várias espécies, como Solanum tuberosum (Kodym et al., 1999).

A presença de janelas externas nas salas de cultura in vitro pode ser uma alternativa satisfatória para iluminação artificial. A idéia inicial é de se manter a sala com altos padrões de higiene, similares às salas de crescimento. A decisão pró ou contra dependerá da cultura, da técnica in vitro utilizada e das condições climáticas. As principais vantagens são: não há custos com iluminação, simplificação das instalações, portanto baixos custos com construção, reduzida necessidade de manutenção de partes adicionais e baixo estresse para aclimatação das plantas (Kodym et al., 1999).

\subsubsection{Temperatura}

Quanto à temperatura, dentro dos frascos ela se apresenta $1^{\circ} \mathrm{C}$ acima da do ambiente fora do frasco, durante o fotoperíodo em condições convencionais de cultivo. Em muitas salas de crescimento a temperatura varia entre períodos de claro/escuro ao redor de $22-26^{\circ} \mathrm{C}$ suprindo razoavelmente o termoperíodo, entretanto, a informação do efeito da temperatura in vitro é inconclusiva (Aitken_Christie, 1995).

Geralmente, temperaturas abaixo de $17^{\circ} \mathrm{C}$ e acima de $32^{\circ} \mathrm{C}$ são consideradas inadequadas para o crescimento de plantas de cultura de tecidos, enquanto que plantas tropicais e subtropicais são cultivadas em temperaturas levemente mais altas que espécies temperadas.

A influência dos fatores que compõem o ambiente de cultivo é muito importante, 
já que exerce grande efeito morfogenético no desenvolvimento da planta in vitro. No caso específico da bananeira, as condições do ambiente variam entre laboratórios, principalmente em relação à luminosidade e temperatura. Quanto à intensidade luminosa, existem registros que vão de 1.000 lux a 3.000 lux, enquanto a temperatura varia de $25^{\circ} \mathrm{C}$ a $30^{\circ} \mathrm{C}$. O fotoperíodo normalmente adotado é de 16 horas, e em alguns laboratórios também se controla a umidade relativa, que fica dentro da faixa de $50 \%$ a $80 \%$. Porém é interessante salientar que, na fase de estabelecimento, os explantes podem ser colocados no escuro, a fim de reduzir as taxas de liberação de polifenóis (Souza et al., 1997).

\subsection{Variação Somaclonal em bananeira:}

A ocorrência de variação somaclonal, ou seja, a variação genética entre plantas regeneradas por cultura de tecidos, é um problema para a micropropagação e conservação in vitro de germoplasma, porém tem um potencial benéfico em termos de criar variabilidade para o melhoramento da bananeira (Souza et al., 1997).

A ocorrência de modificações genéticas durante o processo de cultivo in vitro, de células e tecidos vegetais, já é bem conhecida, tanto no meio acadêmico como nas biofábricas comerciais. Várias destas modificações são manifestadas como mutações na progênie de plantas regeneradas.

Esta expectativa, de uma nova ferramenta no desenvolvimento da variabilidade genética em programas de melhoramento, levou o meio científico a desenvolver estudos em diferentes culturas como batata, cana-de-açúcar, arroz, milho e banana.

A variação somaclonal refere-se a toda variabilidade observada entre plantas regeneradas do cultivo in vitro. Essas variações podem ser de origem epigenética ou herdável (Duncan, 1997). A variação epigenética é temporária ou transiente, normalmente decorrente da alteração no grau de juvenilidade dos explantes durante o cultivo in vitro, associados a um possível efeito residual de reguladores de crescimento presentes no meio de cultivo, da cultivar utilizada, sua idade, grau de ploidia, fonte de explantes, número de subcultivos in vitro e pressão de seleção às condições culturais 
(Skirvin et al., 1994). A variação herdável mantém-se estável após ciclos sexuais e por propagação vegetativa contínua. A variação somaclonal estável decorre de alterações cariológicas, rearranjos cromossomiais ou gênicas (Phillips et al., 1994). Existe também a variação somaclonal estável resultante da variação genética existente no explante, ao invés de ser induzida durante o cultivo in vitro. A variação pré-existente decorre principalmente da desuniformidade de explantes multicelulares com nível de ploidia diferenciado que resultam na formação de quimeras.

A variação somaclonal induzida e estável deriva de fatores intrínsecos de genótipos e de fatores induzidos durante o cultivo in vitro. $\mathrm{O}$ tipo de explante, a composição do meio de cultura, a formação de brotações adventícias, número de subcultivos, duração dos cultivos e o nível de organização do tecido em cultivo têm sido considerados os fatores que possivelmente induzem a variação somaclonal (Israeli et al., 1996). Explantes originados de tecidos organizados tais como: meristemas ou brotos axilares (pré-formados) são menos propensos à variação, do que gemas adventícias, derivadas de embriogênese ou organogênese através de uma fase de formação de calo (dediferenciação). A maior duração da cultura in vitro aumenta a variabilidade devida, um acúmulo de mutações e/ou ploidia no período. Aliado a esse fator, pode ocorrer um aumento na taxa de mutação em cada geração, e/ou uma seleção ativa para mutações induzidas no início do ciclo de cultivo (Duncan, 1997). Cotê et al. (1993), demonstraram num modelo matemático a importância do número de subcultivos e duração do cultivo in vitro da bananeira, no percentual de variantes somaclonais obtidos. Fatores intrínsecos que afetam a variabilidade somaclonal incluem a estabilidade genética da variedade ou genótipo cultivado.

As causas da variação somaclonal foram revisadas por Duncan (1997), e incluem: ruptura do ciclo mitótico das células pela aneuploidia/poliploidia; rearranjos cromossomais decorrentes de quebra de cromossomos (inversões, deleções e translocações); transposons; "crossover" somáticos e alteração no grau de metilação de DNA.

Segundo Cotê et al., (1993) as variações tem sido principalmente notadas em tamanho de plantas, morfologia da inflorescência e presença de diferentes anormalidades 
foliares. As bases genéticas dos fenótipos de variação em banana, não são claras.

Segundo Shepherd (1990), em banana já se detectaram freqüências de variações somaclonais que variam de $1 \%$ a $25 \%$, tornando-se dificil prever o número de plantas anormais. As variações podem afetar características vegetativas ou da inflorescência, e sua freqüência depende da variedade, dos tipos de explantes, dos componentes do meio de cultura e do tempo de permanência das plantas in vitro (Dantas et al., 1997)

Os principais tipos de variantes somaclonais em bananeira incluem o nanismo, que chega a representar até $80 \%$ dos casos dos variantes (Reuveni et al., 1993; Israeli et al., 1996; Damasco et al., 1996). Outros variantes de banana incluem alterações na filotaxia e formato da folha, com encurtamento entre nós (Arias, 1993). As principais características alteradas durante o cultivo in vitro também ocorrem como mutações naturais, mas em menor freqüência (Cotê et al., 1993; Whiters, 1993).

$\mathrm{Na}$ Austrália, o uso de mudas micropropagadas comercialmente, produziu inicialmente cerca de $90 \%$ de mudas fora de padrão, e tem causado uma certa resistência a aceitação desse tipo de muda pelo agricultor.

Existem indicações que a ocorrência de variantes somaclonais em Musa estão associados a alterações genéticas, variando de alterações cromossomiais (aneuploidia) até a nível de seqüência de DNA, e que devem ser usados para a detecção precoce de variantes (Whiters, 1993). A deteç̧ão precoce de variantes somaclonais permitiria ajudar na elucidação das causas do fenômeno em Musa, possibilitando a manipulação dos fatores causadores, para minimizar a ocorrência para conservação de germoplasma in vitro ou na micropropagação comercial, ou para maximizar a variabilidade para identificar mutantes favoráveis.

Rodrigues, 1996 estudou no Brasil, o efeito do número de subcultivos, na ocorrência de variação somaclonal, em mudas de bananeira micropropagadas e também foram avaliados os diferentes tipos de variantes encontrados. Os resultados indicaram que o aumento no número de subcultivos aumentava a taxa de variação somaclonal. Observou-se que a variedade Grande Naine apresentou uma taxa maior de variação que a variedade Nanicão, indicando uma maior instabilidade genética no sistema in vitro. A avaliação econômica, em três situações de produção simuladas, com 3,6 e 9 subcultivos, 
indicou ser pequena a vantagem do uso de 9 subcultivos. Portanto, recomenda-se um máximo de 6 subcultivos.

Por estas razões, o conhecimento dos mecanismos de variação somaclonal e o desenvolvimento de métodos precoces para detectá-la é um fator chave na adoção da micropropagação com segurança. Entre os métodos utilizados para detectar essas variações estão a análise citogenética, baseada na contagem de cromossomos (Shepherd, 1984b); a aplicação do marcador molecular tipo RAPD; e o acompanhamento durante o desenvolvimento das plantas (Israeli et al., 1991).

Segundo Shepherd et al., (1986), o melhoramento da bananeira tem se beneficiado com a aplicação de técnicas simples de cultura de tecidos, podendo, num futuro bem próximo, vir a utilizar técnicas in vitro mais complexas. O cultivo de embriões de sementes maduras de banana tem sido praticado durante mais de 20 anos, tendo começado na Jamaica, onde a germinação de sementes/embriões da 'Highgate' aumentou de 20 a $60 \%$. No Brasil, a prática de extração e cultivo in vitro de embriões de banana vem sendo utilizada como mecanismo auxiliar ao programa de melhoramento.

A cultura de ápices caulinares também tem sido bastante utilizada como técnica auxiliar em programas de melhoramento genético da bananeira, constituindo-se num rápido e eficiente método para a propagação vegetativa de plantas (Dantas, 1993), recuperação de plantas livres de doenças (Torres, 1990), conservação de germoplasma (Souza, 1988), bem como na execução de estudos na área de fisiologia.

Há também uma grande necessidade de pesquisa na área de fertilização in vitro e, considerando-se o tamanho e a estrutura dos ovários, a técnica da fertilização de óvulos in vitro deve ser desenvolvida. A pesquisa é necessária pois, dos sacos embrionários disponíveis em ovários de bananeiras partenocárpicas, poucos se tornam fertilizados, ocasionando uma baixa produção de sementes. Sem dúvida, o problema se deve à penetração deficiente dos tubos polínicos. As falhas dos tubos têm sido verificadas em estiletes e em observações diretas de seções de ovários de genótipos diplóides e triplóides, apresentando óvulos não fertilizados. Adicionalmente, as poucas sementes produzidas concentram-se fortemente no ápice extremo da polpa do fruto, e são sempre mais freqüentes no quarto ou na metade apical do fruto, a depender da 
cultivar utilizada. Na base do fruto são raras as sementes encontradas.

Caso uma maior proporção de saco embrionário disponível fosse fertilizada in vitro e os embriões fossem recuperados e postos germinar em meio de cultura apropriado, o incremento na produção de híbridos seria espetacular; talvez até permitisse hibridações de clone que têm apresentado esterilidade feminina total. Com banana entretanto, a técnica encontra-se em fase inicial de investigação; os primeiros esforços têm sido envidados no sentido de definir os meios de cultura favoráveis à germinação do pólen e ao contínuo crescimento do tubo polínico. 


\section{MATERIAL E MÉTODOS}

O trabalho foi conduzido no laboratório de Melhoramento de Plantas do Centro de Energia Nuclear na Agricultura (CENA/USP), Piracicaba - SP. O município de Piracicaba é de clima Cwa, tropical de altitude, com inverno seco e verão úmido, segundo a classificação de Köppen. A latitude de Piracicaba é de S $22^{\circ} 43^{\prime} 30^{\prime \prime}$, a longitude é de $47^{\circ} 38^{\prime} 0^{\prime \prime}$ com altitude de 554 metros.

\subsection{Material vegetal, obtenção de explantes e micropropagação:}

O material usado como matriz, no processo de micropropagação do experimento, foi constituído de rizomas (brotos laterais $=$ chifrinhos) selecionados de bananeiras de cultivares comerciais: Grande Naine (AAA) e Maçã (AAB), com características favoráveis, obtidas numa fazenda na cidade de Fernandópolis, estado de São Paulo.

O cultivar Grande Naine, de origem das colônias francesas no Caribe, foi introduzido no Brasil há 30 anos, especificamente no Vale do Ribeira, apresentando características muito semelhantes ao Nanicão, diferenciando-se basicamente na altura da planta. Com uma altura relativamente menor que o cultivar Nanicão, o Grande Naine adapta-se melhor a regiões de ventos fortes.

Possui boas características quanto à produtividade e qualidade de fruto, e os cultivares pertencentes ao subgrupo Cavendish, são resistentes às raças 1 e 2 do Fusarium, e são a nível mundial, os clones de maior cultivo e importância comercial.

O cultivar Maçã é um híbrido triplóide, bananeira de fruto delicado, disseminado por quase todo país. Apresenta o pseudocaule de 3,5 a $4 \mathrm{~m}$ de altura, verde-amarelado brilhante, com poucas a diminutas manchas de cor escura. As folhas são revestidas de 
cerosidade na parte inferior. Os frutos são curtamente pedunculados, roliços, de casca fina e delicada, amarela, endocarpo de cor branca, macio, delicado, doce, de sabor semelhante ao da maçã. Cachos relativamente pequenos, pesando em média 15 quilos, com 5 a 10 verticilos e 60 a 150 bananas. A banana mede de 10 a $16 \mathrm{~cm}$ de comprimento e pesa de 100 a 200 gramas.

\subsection{Produção de Mudas de Bananeira Micropropagadas}

A partir de janeiro de 1998, foram selecionadas as primeiras brotações laterais, utilizadas neste trabalho. Após a seleção do material no campo, seguiu-se o isolamento dos ápices caulinares e sua introdução in vitro. Os rizomas passaram por um processo de limpeza antes de serem levados ao laboratório, a fim de eliminar focos de contaminação que poderiam trazer do campo. Para isso foram retiradas manualmente e com auxílio de facão as folhas mais externas, até que o rizoma ficou com aproximadamente $7,0 \mathrm{~cm}$ de comprimento por $2,5 \mathrm{~cm}$ de diâmetro.

Em seguida, os rizomas foram levados ao laboratório, submetidos a um rápido banho de álcool (96\%), com a finalidade de quebrar a tensão superficial dos tecidos. $\mathrm{Na}$ sequência, os rizomas foram mergulhados em solução de água e hipoclorito de sódio ( $2 \%$ de cloro ativo) na proporção de 1:1, por aproximadamente 25 minutos. Após o tratamento asséptico, os rizomas foram lavados em água destilada estéril, por 4 vezes, no interior da câmara de fluxo laminar.

Terminada a lavagem, com auxilio de pinça e bisturi, foram isolados os ápices caulinares, que envolvem o meristema. O ápice caulinar foi então, introduzido em frascos de $200 \mathrm{~mL}$ com 50mL de meio de cultura MS (Murashige \& Skoog, 1962), com adição de 2,5 $\mathrm{mgL}^{-1}$ de 6-benzilaminopurina (BAP), e incubados à temperatura de $27^{\circ} \mathrm{C}$ e fotoperíodo de $16 \mathrm{~h}$ de luz e $8 \mathrm{~h}$ de escuro. Os explantes foram subcultivados para a formação das plântulas após 4 semanas, para posterior transferência para meio MS fresco com adição de 4,5 mgL ${ }^{-1}$ de BAP , para indução de brotações laterais.

Uma vez formadas as brotações, este foi o material utilizado para a instalação do experimento. 
O experimento foi iniciado com a introdução em câmara de fluxo laminar de 26 ápices caulinares de cada cultivar de banana (cultivo zero), sendo um ápice caulinar por frasco. Destes, 13 frascos foram levados para as condições de telado e os outros 13, para as condições de sala de crescimento.

\subsection{Micropropagação em diferentes condições ambientais e épocas dos anos} de 1998 a 2000:

A micropropagação foi efetuada em dois ambientes, durante três épocas dos anos de 1998 a 2000.

Um dos ambientes referiu-se à sala de crescimento e o outro, o telado (ausência de custos com iluminação, simplificação das instalações, baixo custo da construção, baixo estresse para as plantas durante a aclimatação).

As épocas dos anos em que foram efetuadas as micropropagações, foram as seguintes:

$$
\begin{aligned}
& \text { Época } 1-21 / 08 / 98 \text { a 02/11/98 } \\
& \text { Época } 2-26 / 05 / 99 \text { a 25/09/99 } \\
& \text { Época } 3-15 / 11 / 99 \text { a 15/02/00 }
\end{aligned}
$$

Tanto para a sala de crescimento, quanto para o telado, nas três épocas foram coletados dados pelo aparelho Skye Data Hog, de hora em hora, para que se calculasse posteriormente a média diária, mensal, os valores máximos e também mínimos de umidade, temperatura e luminosidade nos dois diferentes ambientes.

\subsection{Condições de Telado:}

O telado é revestido com sombrite nas laterais e a cobertura é plástica, onde as mudas micropropagadas ficaram dispostas em estantes com iluminação natural e com monitoramento pelo aparelho Skye Data Hog. 


\subsection{Condições de Sala de crescimento:}

A sala de crescimento é de alvenaria, com uma área de aproximadamente $6 \mathrm{~m}^{2}$, paredes brancas. As plantas micropropagadas foram expostas à luz fluorescente nas estantes, não foi utilizado nenhum tipo de sombreamento. A temperatura $\left(26-29^{\circ} \mathrm{C}\right)$ e o fotoperíodo (16 horas de luz) foram controlados por um timer que regulou o funcionamento das lâmpadas e do ar condicionado.

\subsection{Condução do experimento:}

A composição do meio de multiplicação in vitro de bananeira que foi utilizado: meio MS (Murashige \& Skoog, 1967) acrescido de vitamina MS $10 \mathrm{mgL}^{-1}, 40 \mathrm{~mL}^{-1} \mathrm{de}$ cisteína; $1 \mathrm{mgL}^{-1}$ de tiamina; $45 \mathrm{gL}^{-1}$ de sacarose, $2 \mathrm{gL}^{-1}$ de phytagel, (Sigma Corporation) $4,5 \mathrm{~mL}^{-1}$ de BAP, para banana Grande Naine e a mesma composição do meio anterior apenas com modificação para a vitamina, a qual foi a de Morel para banana Maçã. Ambos os meios tiveram o seu $\mathrm{pH}$ ajustado para 6,1 e em seguida foram distribuídos em frascos de vidro contendo $60 \mathrm{~mL}$. Os mesmos foram esterilizados em autoclave à temperatura de $121^{\circ} \mathrm{C}$ por 20 minutos. Nos meios de enraizamento, apenas o BAP foi omitido.

Os explantes permaneceram, em telado e em sala de crescimento por 30 dias. Decorrido este tempo, os explantes foram repicados, as brotações foram excisadas e transferidas para meio de multiplicação com igual composição ( $1^{\underline{a}}$ repicagem).

O material foi novamente cultivado por mais 30 dias, quando então foi feita uma limpeza dos explantes (retirada de tecidos oxidados e/ou mortos), separação dos brotos e subcultivo para meio fresco ( $2^{\underline{a}}$ repicagem). Esse procedimento foi repetido mais uma vez até a terceira repicagem, onde as plantas foram limpas e inoculadas em meio específico para enraizamento. $O$ meio de enraizamento teve a mesma composição do meio de multiplicação à exceção do acréscimo de BAP, portanto, este meio de enraizamento não conteve reguladores de crescimento. Os frascos foram numerados de forma que se determinasse a quantidade total de brotações obtidas em cada ápice 
caulinar introduzido. Ao final de cada uma destas operações descritas, os frascos retornavam ao telado ou a sala de crescimento. Desta forma, pode-se determinar o número de brotações obtidas em cada ciclo de subcultivo e, no final, o número total de brotações obtidas em cada explante e em cada ambiente durante as 3 épocas do ano em que o trabalho foi conduzido.

A fase seguinte foi de aclimatação das plantas. Para isto, plantas (in vitro) enraizadas foram retiradas dos frascos e levadas para bandejas contendo vermiculita autoclavada e permaneceram em câmara úmida (umidecidas com nebulizador) por uma semana. Após este período, as bandejas com as plantas, foram retiradas e levadas para um local sombreado e fresco (estufa) e passaram a ser molhadas manualmente com o auxilio de mangueira até atingirem um tamanho ideal para serem transplantadas em substrato comercial Plantimax.

Para a avaliação do experimento foi considerada a taxa média de multiplicação (média do número de brotações) das plantas durante os 3 subcultivos, nos dois locais, nas três épocas do ano e o número total de mudas produzidas por explante. A qualidade das mudas também foi levada em consideração, observando-se o tamanho, a presença de deficiências.

\subsection{Levantamento de produtos, serviços para posterior cálculo de custos de mudas produzidos nos dois ambientes:}

Foi realizado um levantamento do preço dos diversos equipamentos, serviços, produtos químicos, para que fosse possível o cálculo, em cada ambiente, do preço da muda produzida. Os dados utilizados encontram-se nos Quadros de 1 a 4.

\section{8 . Delineamento Experimental}

O experimento foi montado utilizando-se o delineamento inteiramente casualizado, tanto para banana Grande Naine quanto para Maçã. Para a análise considerou-se como, Tratamento 1 os dados obtidos em Sala de Crescimento e 
Tratamento 2 os obtidos em Telado. Para os dois tratamentos os dados foram coletados em três épocas distintas que foram: Época 1 - 21/08/98 a 21/11/98; Época 2 - 26/05/99 a 25/09/99 e Época 3 - 15/11/99 a 15/02/00.

Foram utilizadas 13 repetições para as duas primeiras repicagens e 12 para a terceira (total de trinta e oito observações), sendo uma planta mãe em cada frasco, isto para cada um dos dois tipos de banana nos dois locais propostos, nas três diferentes épocas do ano.

A análise estatística foi primeiramente feita pelo ajuste do modelo de Poisson, padrão aos dados, mostrando evidências de possível superdispersão por isto decidiu-se utilizar a distribuição binomial negativa que se ajustou bem aos dados.

Para a análise estatística foram considerados os dados totais, isto é somatório do número de brotos das três repicagens, não sendo realizada portanto uma análise estatística para cada uma das três repicagens. Foi também realizada uma análise não seqüencial denominada Tipo 3 devido aos tratamentos em relação às épocas não serem variáveis dependentes. É uma análise onde se observa a significância do tratamento e da época, caso não exista interação entre estes, as variáveis não precisarão ser analisadas em conjunto. 


\section{RESULTADOS E DISCUSSÃO}

Os cultivares de bananeira apresentam uma lenta taxa de multiplicação no campo, que varia de 5 a 10 mudas/planta matriz/ano, dependendo do genótipo e condições edafoclimáticas de cultivo. Por outro lado, pode-se obter pelo menos 250 mudas/planta matriz/8 meses utilizando-se técnicas de cultura de tecidos in vitro (Oliveira; 1998). Há, portanto uma possibilidade de otimização de produção de mudas com uso da técnica de cultura de tecidos.

A eficiência do sistema de produção de mudas de bananeira por cultura in vitro de tecidos é comprovada, sendo utilizada com sucesso em inúmeras empresas. Em geral, o custo unitário de produção das mudas em laboratórios de micropropagação é inversamente proporcional ao número total de plantas produzidas. Empresários do setor afirmam que apenas os laboratórios com capacidade de produção superior a 300 mil mudas por ano podem ser viáveis economicamente (Oliveira; 1998).

A mão-de-obra é o principal componente do custo de produção de um laboratório de produção de mudas, representando $40-70 \%$ do custo total em função da região e do sistema utilizado para a micropropagação (Oliveira; 1998).

$\mathrm{Na}$ busca de uma diminuição de custos para que a micropropagação fosse acessível ao produtor, estão relacionados todos os dados coletados pelo aparelho Skye Data Hog, de Temperatura, Luminosidade e Umidade relativa, visando conseguir essa redução em uma das muitas etapas da micropropagação. Os dados obtidos para a sala de crescimento e telado podem ser vistos nas Tabelas 1 e 2 respectivamente. Ao contrário do que seria esperado, observam-se (Tabela 1) variações acentuadas na sala de crescimento, especialmente para a temperatura, que variou de $24^{\circ} \mathrm{C}$ a $34^{\circ} \mathrm{C}$. Dentre os vários fatores que poderiam explicar essas variações, destaca-se a ocorrência de quebra 
de um dos aparelhos de ar condicionado e abertura freqüente da porta. Mas de qualquer modo, quando se observam essas variações, verifica-se que elas foram menores em comparação com as encontradas para as diferentes épocas no telado em que o experimento foi realizado. De fato, para a primeira época por exemplo, a umidade relativa variou de 15,5 a $100 \%$, a temperatura de 10,6 a $40,6^{\circ} \mathrm{C}$ e a luminosidade de 0 a $431,57 \mu \mathrm{mol} / \mathrm{m}^{2} / \mathrm{s}$ (Tabela 2) . Na segunda época, foram observados os menores valores médios de temperatura (de 16 a $21^{\circ} \mathrm{C}$ ), encontrando-se os valores maiores para a terceira época $\left(22\right.$ a $\left.25^{\circ} \mathrm{C}\right)$ e intermediários para a primeira época $\left(21\right.$ a $\left.24^{\circ} \mathrm{C}\right)$. Existiu também grande variação para entre os valores máximos de luminosidade média entre as três épocas, sendo os maiores valores para a primeira época $\left(431,57 \mu \mathrm{mol} / \mathrm{m}^{2} / \mathrm{s}\right)$, os menores para a terceira ( 0 a $\left.135,60 \mu \mathrm{mol} / \mathrm{m}^{2} / \mathrm{s}\right)$ e valores intermediários para a Segunda $(265,19$ $\mu \mathrm{mol} / \mathrm{m}^{2} / \mathrm{s}$ ). Essas variações observadas em telado podem influenciar no número de mudas obtidas nas diferentes épocas.

O número de brotações nas três diferentes épocas para os dois cultivares, está descrito nas Tabelas de 3 a 14 .

Pelos dados destas Tabelas, observam-se grandes variações no número de brotos produzidos e estas variações ocorreram tanto para as diferentes repicagens, quanto para épocas e local onde o material foi desenvolvido. Assim é que por exemplo verificandose o número de brotos para banana Maçã obtidos em condição de telado na primeira repicagem, observa-se que variou de 2 (Tabela 8, Época 2) a 8 (Tabela 4, Época 1) enquanto que para as mesmas condições a variação para Grande Naine foi de 4 (Tabela 14, Época 3) a 11 (Tabela 6, Época 1). Evidentemente o número de brotos obtidos na primeira repicagem irá afeta o número total de brotos obtidos após as três repicagens. Sob este aspecto, nota-se que na primeira repicagem, tanto para condições de telado como para sala de crescimento, observou-se uma tendência do cultivar Grande Naine apresentar um número maior de brotos do que o cultivar Maçã. Vários fatores podem explicar estas diferenças iniciais, tais como influência do cultivar (maior ou menor eficiência na multiplicação), contaminações ou influência do ambiente, como no presente trabalho. Na fase de multiplicação (subcultivos de 1-3), obteve-se uma porcentagem média de contaminação de 15\% para banana Maçã e de aproximadamente 
6\% para banana Grande Naine. Na fase de multiplicação, verificou-se em cada ciclo de 30 dias de cultivo, que na primeira semana ocorreu um pouco de oxidação dos explantes, decorrente da liberação de compostos fenólicos, e isto ocorreu mais acentuadamente no cultivar Maçã. A experiência do Laboratório de Melhoramento de Plantas em trabalhos com o cultivar Maçã indica que ele sempre tem apresentado taxas menores de multiplicação e este, juntamente com os outros fatores citados podem explicar estas variações observadas.

Após as 3 repicagens, as mudas obtidas em todos os tratamentos foram aclimatadas, anotando-se a sobrevivência e neste caso, para os dois cultivares, as perdas durante a aclimatação foram da ordem de 1,0\% independendo de sua origem ou época. $O$ aspecto das mudas de ambos os locais e épocas foi semelhante, não se observando diferenças entre variegações ou conformação de folhas.

A partir dos dados relatados nas Tabelas de 3 a 14, foi realizada a análise estatística, para o cultivar Grande Naine e para o Maçã, considerando-se ambientes como tratamentos e as três épocas, de acordo com o que foi descrito anteriormente (item 3.8)

Para os resultados da análise estatística, feita pelo ajuste do modelo de Poisson padrão aos dados, os desvios padrões residuais foram 413,0 (com 72 graus de liberdade) e 1193,3 (com 69 graus de liberdade), para as variedades banana Maçã e banana Grande Naine, respectivamente, mostrando evidências de possível superdispersão. Usando "halfnormal plots" (Demétrio \& Hinde, 1997), observa- se claramente pela Figura 1 a falta de ajuste da distribuição Poisson aos dados. 

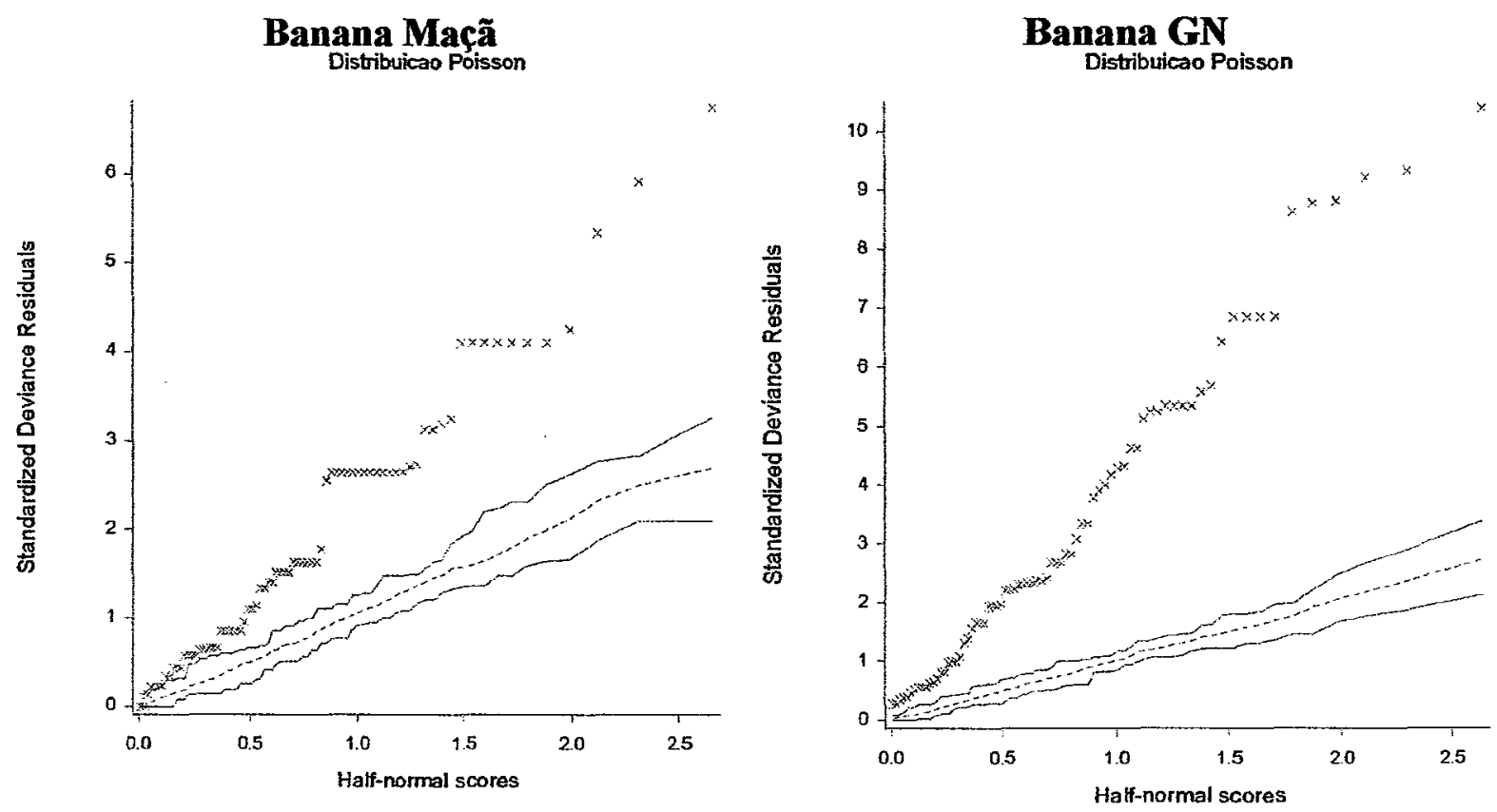

Figura 1 . Distribuição de Poisson para o número total de brotos obtidos dos cultivares Maçã e Grande Naine, em sala de crescimento e telado, durante três épocas.

A distribuição binomial negativa ajustou-se bem aos dados, sendo que para a variedade de Banana Maçã, o desvio padrão residual, foi 83,886 (com 72 graus de liberdade), considerando o modelo com a interação (tratamento + época + tratamento $x$ época). Como a interação não foi significativa, nova análise foi realizada, sem a interação, e o desvio padrão do modelo ajustado (tratamento + época) foi de 83,742 (com 74 graus de liberdade).

Para a variedade de Banana Grande Naine, o desvio padrão residual, foi 87,176 (com 69 graus de liberdade), considerando o modelo com a interação (tratamento + etapa + tratamento $x$ etapa). Como a interação não foi significativa, nova análise foi realizada, sem a interação, e o desvio padrão do modelo ajustado (tratamento + época) foi de 87,210 (com 71 graus de liberdade).

O ajuste da binomial negativa pode ser visualizado através dos "half-normal plots" na Figura 2. 


\section{Banana Maçã}

Dist. Binomial Negativa

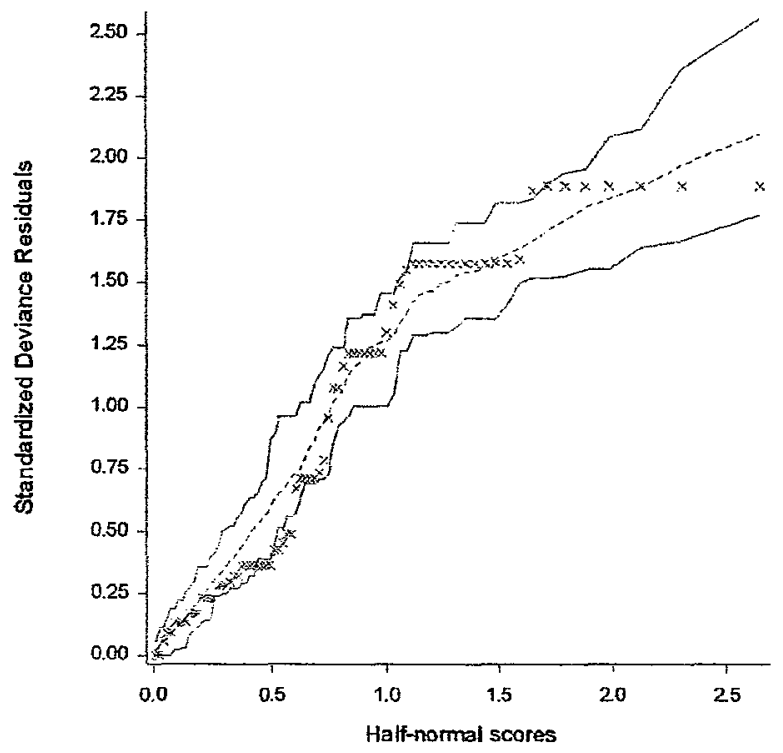

Banana GN

Dist. Binomial Negativa

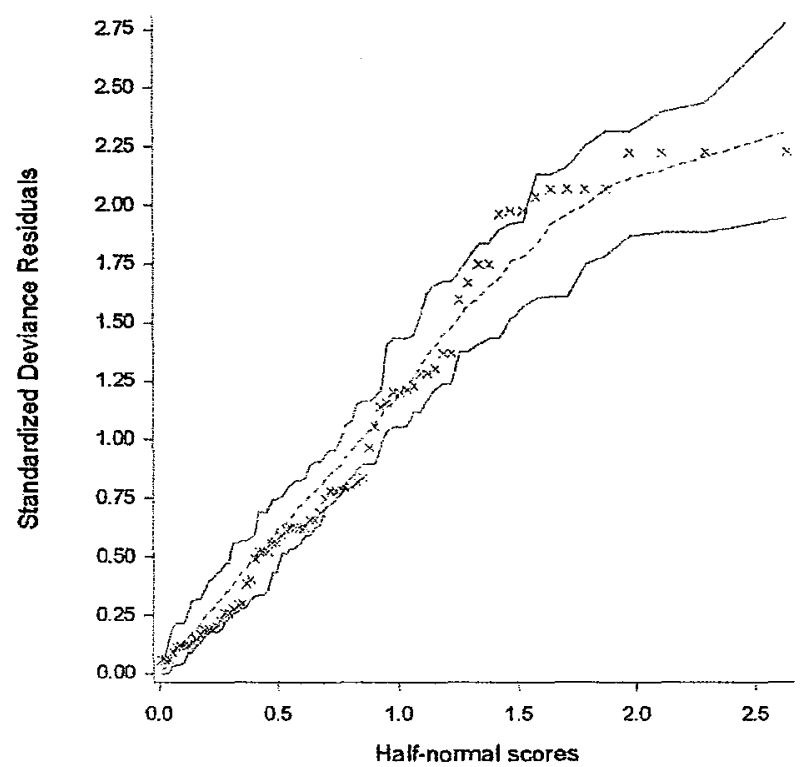

Figura 2 . Distribuição binomial negativa para o número total de brotos obtidos para os cultivares Maçã e Grande Naine, em sala de crescimento e telado, durante três épocas.

Utilizando-se o número de brotos, o programa estatístico usado, buscou uma equação que melhor se ajustasse a esses dados. Quando se colocou o intercepto, neste caso, ele se mostrou significativo, mas todos os outros dados perderam seu valor de significância. Portanto, para as análises a serem relatadas, o intercepto foi zerado,e os fatores apresentaram a sua real interferência. Os resultados da análise encontram-se nas Tabelas 15 a 22.

Verifica-se pelos resultados (Tabelas 15 a 18) que para o cultivar Grande Naine houve diferença estatística entre os tratamentos e que pelos valores médios do número de brotos (Tabela 15), conclui-se que para a sala de crescimento o número médio de brotos $(23,68)$ foi maior do que para o telado $(12,37)$. A análise estatística (Tabela 17) não detectou diferenças significativas entre as épocas, apesar do valor observado (Tabela 16) para a primeira época $(23,04)$ ser numericamente superior à das outras duas $(17,31$ e 14,11). Não existiu interação entre local e época de obtenção de mudas. 
Para banana Maçã os resultados (Tabelas 19 a 22) indicam que houve diferença estatística entre os tratamentos e entre épocas e ausência de interação. Pelos valores do número de brotos (Tabela 19), conclui-se que a sala de crescimento ofereceu as melhores condições para desenvolvimento, resultando em número maior de brotos $(13,01)$ quando comparado com telado $(5,08)$. Neste caso, a análise estatística (Tabela 21) foi capaz de distinguir diferenças significativas entre as épocas, sendo que (Tabela 20) para a primeira obteve-se o melhor resultado para o número médio de brotos produzidos $(9,69)$ quando comparado com as outras duas épocas $(6,81$ e 3,11$)$.

Um aspecto de importância que deve ser destacado nas mudas na micropropagação em telado, é que cuidados adicionais quanto à contaminação, devem ser levados em conta. Isto porque, ao contrário da sala de crescimento, os frascos em telado são expostos a maior número de contaminantes ambientais. Quando são levados para a câmara de repicagem existe necessidade de maiores cuidados em sua desinfecção, quando comparados com os de sala de crescimento.

$\mathrm{Na}$ Tabela 23 pode-se observar o custo dos equipamentos usados num laboratório de cultura de tecidos, suas respectivas marcas e valores e quantidades sugeridas para uma montagem satisfatória, para preparo dos meios, isolamento e multiplicação das mudas micropropagadas.

Verifica-se que o material utilizado para tal finalidade é de precisão e seu valor unitário muito alto. Para um laboratório de funcionamento normal de cultura de tecidos é necessário tanto para o cultivar Maçã quanto para o cultivar Grande Naine, pois ambos passam pela introdução do material e suas repicagens (multiplicação) também são realizadas dentro do laboratório, somente o processo de manutenção dos frascos com as mudas já micropropagadas é que podem usar a sala de crescimento ou o telado. Levandose em conta que não existem diferenças para os dois cultivares para este item, a diferença de custo estará relacionada aos próximos itens que se seguirão.

Na Tabela 24, baseando-se em catálogo comercial, pode-se observar os custos por $1000 \mathrm{~g}$ dos produtos químicos, as quantidades utilizadas para confeç̧ão de um litro de meio de cultura e o custo/litro de meio de cultura usado no processo de repicagem das mudas. Pode-se desta forma chegar num valor de custo por litro do meio de cultura para os dois 
cultivares, lembrando-se que para o cultivar Maçã a vitamina de Morel é usada. Verifica-se que o custo dos meios de cultura tanto para multiplicação quanto para enraizamento (ausência de hormônio - BAP - indução de gemas laterais, quebra da dominância apical e evita a formação de raizes) é bem semelhante e os itens mais onerosos seriam a sucrose e o Phytagel perfazendo $85,45 \%$ do custo/Litro de meio de multiplicação. Sabe-se que já é possível a substituição da sucrose por açúcar cristal, sem alteração na qualidade das mudas obtidas, reduzindo-se bastante o custo.

$\mathrm{Na}$ Tabela 25 foram calculados os gastos com energia elétrica em sala de crescimento, onde o experimento foi conduzido e que possui dois aparelhos de ar condicionado, onze estantes com cinco prateleiras cada, em $8 \mathrm{~m}^{2}$ de área. Em cada prateleira tem quatro lâmpadas fluorescentes, totalizando um número de 220 . O valor do $\mathrm{KW} / \mathrm{h}$ pago ( $\mathrm{R} \$$ 0,19067) para a companhia de força, a quantidade de horas de funcionamento dos aparelhos e o gasto mensal com os aparelhos de ar condicionado e as lâmpadas também foram levados em consideração. Desta forma se pode numa estimativa de gasto com energia elétrica mensal, onde as lâmpadas são responsáveis por $64,83 \%$ do valor da energia elétrica gasta na sala de crescimento.

Ainda com relação aos custos com energia elétrica, calculou-se o gasto com o uso de microondas e de autoclave, no preparo dos meios de cultura, sendo considerados tanto na sala de crescimento quanto em telado, uma vez que em ambos locais houve utilização do meio para multiplicação das mudas de banana Grande Naine e Maçã. Observa-se pela Tabela 26, que estes gastos foram reduzidos em comparação com os das Tabelas 25 e 24 sendo o custo com a autoclave maior que o forno de microondas.

Com os dados das Tabelas 24, 25 e 26, pode-se calcular o custo total de produtos químicos, energia elétrica na produção de mudas.

Ao todo, na sala de crescimento, foram usados nestas três épocas, $12,55 \mathrm{~L}$ de meio de multiplicação e 3,4L de meio para enraizamento e foi obtido um total de 337 brotos para banana Maçã. Também, foram usadas nestas 3 épocas 20,35L de meio de multiplicação e 9L de meio de enraizamento e um total de 900 brotos para banana Grande Naine.

Ao todo, no telado, foram usados nestas três épocas, $11,5 \mathrm{~L}$ de meio de multiplicação e 1,82L de meio para enraizamento e foram obtidos 182 brotos para banana 
Maçã. Também foram usados nestas três épocas, 14,1L de meio de multiplicação e 4,7L de meio de enraizamento e foram obtidos 470 brotos para banana Grande Naine.

O custo final por muda produzida, levando-se em conta os dados citados anteriormente, encontra-se na Tabela 27. Verificou-se para os dois cultivares que o custo de produção das mudas foi menor em condições de telado. Levando-se em conta que não existiram diferenças no custo dos produtos químicos, podemos debitar esta diferença nos gastos com energia elétrica utilizada na iluminação e refrigeração que existem na sala de crescimento (Tabela 25), já que o microondas e autoclave foram utilizados nos dois ambientes (Tabela 26).

Outro fato a ser destacado, é que nos dois ambientes, o número de mudas produzidas para o cultivar Grande Naine foi superior ao Maçã, o que acarreta num maior gasto para produção de mudas no segundo cultivar. Para a mesma quantidade final de mudas produzidas, deverá se ter um número inicial de explantes maior, bem como maior quantidade de litros de meio de cultura, maior número de estantes para dispor as vidrarias, entre outros. Sabe-se que a taxa de multiplicação depende do cultivar e que em empresas de produção de mudas in vitro, a taxa média de multiplicação varia de 1,5 a 3,0 em relação a cultivares do subgrupo Cavendish estabelecidas em meio de cultura. Isto tem sido observado por outros pesquisadores o que também ocorreu neste trabalho. Mas verifica-se que apesar dos cultivares apresentarem taxas de multiplicação e custos de produção diferentes, a redução no custo em condições de telado, levando-se em conta o gasto na produção de sala de crescimento ( $\mathrm{R} \$ 0,312$ para Grande Naine e $\mathrm{R} \$ 0,781)$ foi próxima para os dois cultivares: De fato, pode-se calcular que a redução no custo em telado foi de $81,1 \%$ para o cultivar Grande Naine e de $85,40 \%$ para o Maçã.

Na Tabela 28 pode-se observar os custos na implantação da sala de crescimento, os aparelhos utilizados para refrigeração e iluminação, os materiais elétricos para instalação, o trabalho de um profissional da área de eletricidade, os componentes internos da sala, os materiais para construção da sala de crescimento, na falta de local adequado já previamente existente, a mão-de-obra de um construtor por empreita fechada e o valor final destes custos.

Verifica-se que os custos relacionados com a construção de uma sala de 
crescimento, apresentam valor muito alto e que a opção de se utilizar um cômodo já existente e apenas reformá-lo apresentaria um abatimento do valor da Tabela 28.

Os valores dos materiais elétricos usados também são altos, devendo ser cotados na época da instalação da sala, mas atendendo às especificações da Tabela 28.

$\mathrm{Na}$ Tabela 29, é possível de se observar o custo por metro quadrado de um telado aos moldes do utilizado no trabalho e que atende as necessidades de produção das mudas apresentando uma estrutura bem simplificada de construção, com laterais de sombrite , cobertura plástica e estrutura de sustentação em madeira.

Verifica-se que o custo por $\mathrm{m}^{2}$ para a implementação de um telado como o usado no presente trabalho é bem baixo quando comparado ao da sala de crescimento (Tabelas 29 e 28 respectivamente), conclui-se portanto que tanto pelo menor custo na produção de mudas como da infra-estrutura usada, pode ser de interesse o uso de telado. Entretanto, foi verificado que para os dois cultivares, houve uma redução no número total de mudas produzidas em condição de telado e isto pode exigir um espaço fisico relativamente maior para a produção de um certo número de mudas necessário para plantio em época determinada e isto precisa ser considerado quando da aplicação desse método.

O menor número de mudas produzidas nos dois cultivares, em condição de telado, deveu-se sem dúvidas à falta de controle de temperatura e de luminosidade, que ocorre em sala de crescimento. De fato, os dados de temperatura e luminosidade apresentaram grandes variações durante as três épocas, existindo temperaturas não adequadas ou também pouca luminosidade que certamente contribuíram para um número menor nas condições de telado. Vários autores têm destacado o papel importante de fatores tais como adequada iluminação e temperatura para aumento na eficiência das técnicas de cultura de tecidos (Kamada et al., 1995; Aitken-Christie et al., 1995; Souza et al., 1997; Kodym et al., 1999). Mas também existem grandes preocupações com diminuições de custos, estudando-se por isto, métodos de automatização, condições mínimas para micropropagação, uso de luz natural, etc (Aitken-Christie et al., 1995; Banejee, 1985; Kodym \& Árias, 1999).

Levando-se todos estes fatores em conta, os resultados do presente trabalho indicam que devido aos menores custos envolvidos na instalação e os menores custos 
das mudas produzidas, se o local utilizado para micropropagação em condições de telado, não tiver temperaturas muito baixas durante o ano, e tiver boa insolação o método pode ser de interesse para atender a produção de mudas da região ou um programa de melhoramento desenvolvido em tal localidade. 


\section{CONCLUSÕES}

O uso de telado, com iluminação natural e sem o controle de temperatura, em três épocas distintas dos anos de 1998 a 2000 , permitiu a redução de $81,1 \%$ no custo de mudas micropropagadas para o cultivar Grande Naine e de 85,4 \% para o cultivar Maçã, quando comparado com o de sala de crescimento onde havia iluminação e controle de temperatura com aparelhos de ar condicionado. Tal redução foi devido aos menores custos energia e além disto, outra vantagem para o telado é que seu custo de instalação é bem menor.

Em condições de telado houve uma redução no número de brotações produzidas in vitro, para os dois cultivares. Para o cultivar Grande Naine, o número de brotações não dependeu da época, mas isto ocorreu para o cultivar Maçã, existindo época em que o número de brotações foi maior.

Independentemente do local e época, houve tendência do cultivar Maçã apresentar redução no número de brotos produzidos in vitro.

$\mathrm{O}$ uso do telado para produção de mudas de banana micropropagadas de baixo custo é possível, mas deve-se levar em conta a taxa de multiplicação do cultivar e as condições de temperatura e luminosidade do local nas épocas escolhidas para a micropropagação. 


\section{REFERÊNCIAS BIBLIOGRÁFICAS}

ANCORA, G.; BENVENUTO, E.; SONNINO, A.; CUOZZO, L. Coltore in vitro e mutagenesi nelle piante a moltiplicazione vegetativa. In: MANNINO, P., ed Mutagenesi applicata al miglioramento genetico delle piante a propagazione vegetative. Roma: Cassaccia, 1982.p.41-61.

ARIAS, O. Commercial micropropagation of banana. In: INIBAP. Biotechnology applications for banana and plantain improvement. Montpellier: INIBAP.1993, p.139-142.

AITKEN-CHRISTIE; KOZAI, T.; SMITH, M.A.L. Automation and environmental control in plant tissue culture.. Dordrecht: Kluwer Academic Publisher, 1995. $500 \mathrm{p}$.

BANERJEE, N.; DE LANGHE, E. A tissue culture technique for rapid clonal propagation and storage under minimal growth conditions of Musa (Banana and Plantains), Plant Cell Reports, v,4, p,351-354, 1985.

BROERTJES, C.; VAN HARTEN, A. M. Application of mutation breeding methods in the improvement of vegetatively propagated crops. Amsterdam : Elsevier, 1988. 316p. 
CHAMPION, J. El plátano. 1.ed. Barcelona: Editorial Blume, 1967. 247p.

CHEESMAN, E.E.; DODDS, K.S. Genetical and cytological studies of Musa. IV. Certain triploid clones. Journal of Genetics, v.43, p.337-357, 1948.

CONSTANTIN, M.J. Potential of in vitro mutation breeding for the improvement of vegetatively propagated crop plants. In: INTERNATIONAL ATOMIC ENERGY AGENCY. Induced mutations for crop improvement in Latin America. Vienna: IAEA, 1984. p.59-77. (TEC-DOC, 305).

COTÊ, F.X.; PERRIER E.C.; TEISSON, D. Somaclonal variation in Musa sp.: theoretical risks, risks management, future research prospects. In: INIBAP. Biotechnology applications for banana and plantain improvement. Montpellier: INIBAP.1993. p.192-199.

CRONAUER, S.S.; KRICORIAN, A.D. Multiplication of Musa from excised stem tips. Annals of Botany, v.53, p.321-328, 1986.

DAMASCO, O.P.; GRAHAM, G.C.; HENRY, R.J.; ADKINS, S.W.; SMILLIE, M.K.; GODWIN, I.D. Random amplified polymorphic DNA (RAPD) detection of dwarf off-types in micropropagated Cavendish (Musa spp.AAA) bananas. Plant Cell Reports v.16, p.118-123, 1996.

DANTAS, J.L.L.; SHEPHERD, K.; SOARES FILHO, W. dos S.; CORDEIRO, Z.J.M.; SILVA, S. de O. e ; SOUZA, A. da S. Citogenética e melhoramento genético da bananeira (Musa spp). Cruz das Almas: EMBRAPA, CNPMF, $1993.61 p$. (Documentos, 48). 
DANTAS, J.L.L.; SOARES FILHO, W. dos S; OLIVEIRA, J.R.P.; CABRAL, J.R.S.; CUNHA, M.A.P da; FONSECA, N.; SILVA, S.O. de O. Programa de melhoramento genético de fruteiras da Embrapa Mandioca e Fruticultura. Cruz das Almas: Embrapa Mandioca e Fruticultura, 1999. 78p. (Documentos, 87).

DOMINGUES, E.T;; TULMANN NETO, A.; MENDES, B.M.J.; ANDO, A. Efeitos das doses de raios gama em ápices caulinares de baneira (Musa $\mathrm{sp}$ ) desenvolvidas in vitro para indução de mutação. Pesquisa Agropecuária Brasileira, v.29, n.7, p.1091-1098, 1994.

DONINI, B.; MICKE, A. Use of induced mutations in improvement of vegetatively propagated crops. In: INTERNATIONAL ATOMICENERGY AGENCY. Induced mutations for crop improvement in Latin America. Vienna: IAEA, 1984. p.79-98. (TEC-DOC, 305).

DUNCAN, R.R. Tissue culture-induced variation and crop improvement. Advances in Agronomy, v.58, p.201-240, 1997.

ESPINO, R.R.C.; ZAMORA, A.G.; PIMENTEL, R.B. Mutation breeding on selected Philipine fruit crops. In: INTERNATIONAL ATOMIC ENERGY AGENCY. Nuclear techniques and in vitro culture for plant improvement. Vienna: IAEA, 1986. p.429-433.

FAO PRODUCTION YEARBOOK. Roma: FAO, 1995. (FAO Statistics Series).

FNP CONSULTORIA E COMÉRCIO. Agrianual 98. São Paulo, 1998. p. 194-200. 
FORNASIERI, J.L. Estudo da bananeira (Musa sp) oriunda de cultura de tecido e rizoma cultivar Nanicão e cultivar Grande Naine. Piracicaba, 1998. 69p. Tese (Doutorado) - Escola Superior de Agricultura 'Luiz de Queiroz", Universidade de São Paulo.

HAYASHI, M.; FUJITA, N.; KITAIA, Y. AND KOZAI, T. (1992) Effect of sideward lighting on the growth of potato plantlets in vitro. Acta Horticulturae. 319: 163166.

HWANG, S.C.; KO, W.A. Somaclonal variation of bananas screening for resistance to Fusarium wilt. In: INTERNACIONAL WORKSHOP ON BANANA AND PLANTAIN BREEDING STRATEGIES, Cairs, 1987. Proceedings. Cairs, 1987. p.13-17.

ISRAELI, Y.; REUVENI, O; LAHAV.E. Qualitative aspects of somaclonal variations in banana propagated by in vitro techniques. Scientia Horticulturae, v.48, p.71-88, 1991.

ISRAELI, Y.; BEM-ASSAT, D.; REUVENI, O. Selection of banana clones which do not produce dwarf somaclonal variants during in vitro culture. Scientia Horticulture, v.67, p.197-205, 1996.

JEONG, B.R.; FUJIWARA, K; KOZAI, T. Environmental control and photoautotrophic micropropagation. Horticultural Review, v.17, p.123-170, 1995.

KAEMMER, D.; AFZA, R.; WEISING, K.; KAHA, G.; NOVAK, F.J. Oligonucleotide and amplification fingerprinting of wild species and cultivars of banana (Musa spp.). Bio/Technology, v.10, p.1030-1035, 1992. 
KAMADA, H.; TACHIKAWA, Y.; SAI TOU, T.; HARADA, H. Effects of light and growth regulators on adventitious bud formation in horseradish (Armoraria rusticana). Plant Cell Reports, v. 14, p.611-615, 1995.

KRICORIAN, A.D. In vitro culture of bananas and plantains: background, update and call for information. Tropical Agriculture, v.66, p.194-200, 1989.

KODYM, A.; ARIAS, F.J.Z. Natural light as an alternative light source for the in vitro culture of banana (Musa acuminata cv.Grande Naine). Plant Cell Tissue and Organ Culture, v.55, p.141-145, 1999.

KOZAI, T.; KUBOTA, C.; BYOUNG, R.J. Environmental control for the large-scale production of plants through in vitro techniques. Plant Cell Tissue and Organ Culture, v.51, p.49-56, 1997.

LI, Y.A.V; DENG, X.W. Light control of seedling development. Annual Reviews of Plant Physiology and Plant Molecular Biology, v.47, p.215-243, 1996.

MAIA, M. de S. Crescimento e metabolismo secundário em duas condições de luminosidade e cultura in vitro de Plantago major L. Viçosa, 1998. 106 p. Tese (Doutorado) - Universiade Federal de Viçosa.

MATSUMOTO, K.; YAMAGUCCHI, H. Induction and selection of aluminum tolerance in the banana. In: INTERNATIONAL ATOMIC ENERGY AGENCY. Plant mutation breeding for crop improvement. Vienna: IAEA, 1991. p.327342.

MIYASHITA, Y.; KIYAYA, Y.; KOZAI, T. Effects of red and far-red light on the growth and morphology of potato plantlets in vitro: using light emmiting diodes as a light source for micropropagation. Acta Horticulturae, v.393, p.189-194, 1995. 
MOREIRA, R.S. Banana: teoria e prática de cultivo. Campinas: Fundação Cargill, 1987. $335 p$.

MURASHIGE, T.; SKOOG, F. A revised médium for rapid growth and bioassays with tobacco tissues cultures. Physiologia Plantarum, Copenhagenm v.15, p.473-497, 1962.

NEUMAIER, E.E.; BLESSINGTON, M.T. Effect of light and fertilizer rate and source on flowering, growth, and quality of hibiscus. Horticultural Science, v.22, n.5, p.902-904, 1987.

NOVAK, F.J.; AFZA, R.; PHADVIBULYA, V.; HERMELIN, T.; BRUNNER, H.; DONINI, B. Micropropagation and radiation sensitivity in shoot-tip cultures of banana and plantain. In: INTERNATIONAL ATOMIC ENERGY AGENCY. Nuclear techniques and in vitro culture for plant improvement. Vienna: IAEA, 1986. p.167-174.

OLIVEIRA, R.P.; SILVA, S.O. Avaliação de micropropagação comercial em bananeira. Pesquisa Agropecuária Brasileira, v.32, n.4, p.415-420, 1997.

OLIVEIRA, R.P. Infra estrutura e custos de uma laboratório de produção de mudas de bananeira. Cruz das Almas: EMBRAPA, CNPMF, 1998. $17 \mathrm{p}$. (Documentos, 81).

PHILLIPS, R.L.; KAEPPLER, S.M.; OLHOFT, P. Genetic instability of plant tissue cultures: breakdown of normal controls. Proceedings of the National Academy of Science of the USA, v.91, p.5222-5226, 1994. 
REUVENI, O.S.; GOLUBOWICZ, E.Y; ISRAELI, Y. Factors influencing the occurrence of somaclonal variations in micropropagated bananas. Acta Horticulturae, n.336, p.357-364, 1993.

RODRIGUES, P.H.V. Efeito do número de subcultivos na ocorrência de variação somaclonal, em mudas de bananeiras micropropagadas, das cultivares Nanicão e Grande Naine. Piracicaba, 1996. 104p. Tese (Doutorado) - Centro de Energia Nuclear na Agricultura, Universidade de São Paulo.

SANADA, M. Micropropagation of semitropical crops and its appplication to cultivation in Okinawa. In: THIQUYNH, N.; UYEN, N.V. (Eds.) Adapted propagation techniques for commercial crops of the tropics. Stockolm: (s.n.), 1993. p.101-105.

SHEPHERD, K. A bananeira: taxonomia e morfologia. In: SIMPÓSIO BRASILEIRO SOBRE BANANICULTURA, 1., Jaboticabal, 1984. Anais. Jaboticabal: FCAVJ, UNESP, 1984a. p.50-74.

SHEPHERD, K. Contagem de cromossomos. Cruz das Almas: EMBRAPA, CNPMF, 1984b.

SHEPHERD, K.; DANTAS, J.L.L.; ALVES, E.J. Melhoramento genético da bananeira. Informe Agropecuário, v.12, p.11-19, 1986.

SHEPHERD, K. Genetic improvement of bananas in Brazil: aspects related to resistance to genus Mycosphaerella. In: INTERNATIONAL WORKSHOP ON SIGATOKA LEAF SPOT DISEASE OF BANANAS, San Jose, 1989. Proceedings. Montpellier: INIBAP, 1990. p.243-251. 
SHEPHERD, K.; SILVA, S.O.S.; DANTAS, J.L.L. Germoplasma e melhoramento genético da bananeira. Cruz das Almas: s.n., 1992. 27p.

SILVA, S. de O. e; MATOS, A.P. de ; ALVES, E.J. Melhoramento genético da bananeira. Pesquisa Agropecuária Brasileira, v.33, n.5, p.693-703, 1998.

SLVA, S. de O.; ALVES, E.J. Melhoramento Genético e novas cultivares de bananneira. Informe Agropecuário, Belo Horizonte, v.20, n.196, p.91-96, janeiro/fevereiro, 1998.

SIMMONDS, N.W. Los platanos. Barcelona: Blume, 1973. 539p.

SOARES FILHO, W. dos S.; ALVES, E.J.; CORDEIRO, Z.J.M.; CUNHA, M.A.P. da; SHEPHERD, K.; DANTAS, J.L.L.; BORGES, A.L Programa de pesquisa de banana e plátano em execução no CNPMF-EMBRAPA. Cruz das Almas: EMBRAPA, CNPMF, 1990. 15p. (Documentos, 28).

SOUZA, A.S.; DANTAS, J.L.L.; SOUZA, F.V.D.; CORDEIRO, Z.J.M.; SILVA NETO, S.P. A cultura da banana: aspectos técnicos socioeconômicos e agroindustriais. Brasilia: EMBRAPA SPI; Cruz das Almas: EMBRAPA, CNPMF, 1997. 585p.

TAKAGI, H.; QU, Y. Effects of light quality, photoperiod and clod treatment on in vitro bulbing of Garlic shoot Tip. Acta Horticulturae, n.393, p.181-188, 1995.

TAN, Y.P., HO, Y.W., MAK, C.; IBRAHIM, R. "Fatom-1" early flowering mutant derived from mutation induction of grand Nail, a Cavendish banana. Mutation Breeding Newsletter, v.40, p.5-6, 1993. 
TORRES, A.C. Polinização in vitro. In: TORRES, A.C.; CALDAS, L.S. (Ed.) Técnicas e aplicações da cultura de tecidos de plantas. Braślia: ABCTP; EMBRAPA, CNPH, 1990. p.87-97.

VUYLSTEKE, D.; ORTIZ, R.; FERRIS, S.B.; CROUCH, J.H. Plantain improvement. Plant Breeding Review, v.1, p.267-320, 1997.

WHITHERS, L.A. Early detection of somaclonal variation. In: INIBAP. Biotechnology applications for banana and plantain improvement. Montpellier: INIBAP, 1993. p.200-208.

WILSON, G.B. Cytological studies in the Musae, II, Meiosis in some diploid clones. Genetics, v.31, p.471-482, 1946. 
ANEXOS 


\section{LISTA DE QUADROS}

Quadro 1 - Tipos de equipamentos, fornecedores com respectivo Modelo/Marca, usados no laboratório de produção de mudas de banana micropropagadas.

\begin{tabular}{|c|c|c|}
\hline Equipamento & Fornecedor & Modelo/Marca \\
\hline Fluxo laminar & Veco & VLFS - 12 vertical $(1,20 \mathrm{~m})$ \\
\hline Autoclave & MPL & AV 75 / Phoenix \\
\hline Bico de Bunsem & Acielab & Metalic (4 bicos) \\
\hline Destilador & Acielab & $\begin{array}{l}\text { Acielabe/ } 5 \mathrm{~L} / \mathrm{H} \\
\text { AC } 425\end{array}$ \\
\hline Deionizador & Acielab & $\begin{array}{l}\text { DE } 1800 \text { / Permution } \\
50 \mathrm{~L} / \mathrm{H}\end{array}$ \\
\hline Reservatório Água & Acielab & 20 Lts/ Permution \\
\hline Phmetro & MPL & PA 200/ Tecnopon \\
\hline Balança Precisão & Marconi & $\begin{array}{l}\text { AL } 500 / \text { Marte } \\
\text { Max }-500 \mathrm{gr} / \text { sensib. } 0,001 \mathrm{~g}\end{array}$ \\
\hline Balança Analítica & Tecnal & $\begin{array}{l}\text { E } 02-140 \\
\text { Ohaus - Explorer } \\
\text { Max }-210 \text { gr / sens- 0,1mg }\end{array}$ \\
\hline $\begin{array}{l}\text { Estufa de Secagem e } \\
\text { Esterilização }\end{array}$ & MPL & $\begin{array}{l}\text { Q } 317-\text { B } 132 \\
\text { Quimis } 40 \times 45 \times 40\end{array}$ \\
\hline Agitador Magnético & MPL & Simaton \\
\hline Geladeira & & Eletrolux \\
\hline Freezer & & Eletrolux \\
\hline Microondas & & Sharp \\
\hline \multirow{7}{*}{ Vidrarias } & MPL & $\begin{array}{l}\text { Proveta } \\
\text { M/Nalgon (Plástico) } \\
\text { 100/1000/2000ml }\end{array}$ \\
\hline & MPL & $\begin{array}{l}\text { Becker ( 2 de cada ) } \\
\text { M/Naglon ( Plástico ) } \\
50 / 100 / 1000 / 4000 \mathrm{ml}\end{array}$ \\
\hline & MPL & \begin{tabular}{|l|} 
Becker \\
$3000 \mathrm{ml}$ ( vidro)Laborglass \\
\end{tabular} \\
\hline & Acielab & Erlenmeyer $50 / 125 / 500 / 1000 \mathrm{ml}$ \\
\hline & Acielab & $\begin{array}{l}\text { Pipeta graduada Vidrolabor } \\
1 / 2 / 5 / 10 / 25 \mathrm{ml}\end{array}$ \\
\hline & Acielab & Frascos Reagentes Shott 250ml \\
\hline & & Vidros de 50 a $200 \mathrm{ml}$ \\
\hline Pinça & MPL & $\begin{array}{l}\text { Metalic } \\
15 \mathrm{~cm} \\
20 \mathrm{~cm}\end{array}$ \\
\hline Cabo de bisturi & MPL & Guth \\
\hline Lâmina bisturi & MPL & Paramont $11-23 \mathrm{cx} c / 100$ \\
\hline Bastão de vidro & & Laborglass \\
\hline Galão para água & & $50 \mathrm{~L}$ \\
\hline
\end{tabular}


Quadro 2 - Preço (US\$/1000g) de Produtos Químicos para confecção de meios utilizados na multiplicação e enraizamento de mudas micropropagadas de banana Maçã e Grande Naine.

\begin{tabular}{|c|c|c|}
\hline \multicolumn{3}{|c|}{ MACRONUTRIENTES } \\
\hline & & US\$ / $1000 \mathrm{~g}$ \\
\hline $\mathrm{NH}_{4} \mathrm{NO}_{3}$ & Ammonium nitrate & 55,00 \\
\hline $\mathrm{KNO}_{3}$ & Potassium nitrate & 54,40 \\
\hline $\mathrm{CaCl}_{2} .2 \mathrm{H}_{2} \mathrm{O}$ & Calcium chloride & 45,60 \\
\hline $\mathrm{MgSO}_{4} \cdot 7 \mathrm{H}_{2} \mathrm{O}$ & Magnesium sulfate & 40,20 \\
\hline $\mathrm{KH}_{2} \mathrm{PO}_{4}$ & Potassium phosphate & 67,60 \\
\hline \multicolumn{3}{|c|}{ MICRONUTRIENTES } \\
\hline & & US\$ / 1000g \\
\hline $\mathrm{H}_{3} \mathrm{BO}_{3}$ & Boric acid & 35,20 \\
\hline $\mathrm{MnSO}_{4} 4 \mathrm{H}_{2} \mathrm{O}$ & Manganese sulfate & 57,80 \\
\hline $\mathrm{ZnSO}_{4} .4 \mathrm{H}_{2} \mathrm{O}$ & Zinc sulfate & 73,40 \\
\hline $\mathrm{CoCl}_{2} \cdot 6 \mathrm{H}_{2} \mathrm{O}$ & Cobalt chloride & 438,00 \\
\hline $\mathrm{CuSO}_{4} .5 \mathrm{H}_{2} \mathrm{O}$ & Cupric sulfate & 59,30 \\
\hline $\mathrm{Na}_{2} \mathrm{MoO}_{4} .2 \mathrm{H}_{2} \mathrm{O}$ & Sodium molybdate & 126,40 \\
\hline $\mathrm{KI}$ & Potassium iodide & 195,40 \\
\hline \multicolumn{3}{|c|}{ Fe EDTA } \\
\hline & & US\$ / 1000g \\
\hline $\mathrm{Na}_{2}$.EDTA & & 91,60 \\
\hline $\mathrm{FeSO}_{4} .7 \mathrm{H}_{2} \mathrm{O}$ & & 75,30 \\
\hline \multicolumn{3}{|c|}{ VITAMINA DE MOREL } \\
\hline Tiamina & & 362,00 \\
\hline Pantotenato de $\mathrm{Ca}$ & & $1.556,67$ \\
\hline Ácido Nicotínico & & 54,40 \\
\hline Piridoxina & & 880,00 \\
\hline Biotina & & $53.100,00$ \\
\hline \multicolumn{3}{|c|}{ OUTROS } \\
\hline & & US\$ / 1000g \\
\hline \multirow[t]{2}{*}{$\mathrm{C}_{12} \mathrm{H}_{22} \mathrm{O}_{11}$} & Sucrose & 43,30 \\
\hline & Phytagel & 169,60 \\
\hline Hormônio BAP & & $25.200,00$ \\
\hline
\end{tabular}


Quadro 3 - Número utilizado de aparelhos elétricos e lâmpadas para sala de crescimento de mudas micropropagadas.

\begin{tabular}{|l|c|}
\hline \multicolumn{1}{|c|}{ Componentes } & Quantidade \\
\hline Ar condicionado & 02 \\
\hline Lâmpadas & 220 \\
\hline Microondas & 01 \\
\hline Autoclave & 01 \\
\hline
\end{tabular}

Quadro 4 - Componentes, materiais elétricos e mão-de-obra necessários para implantação de uma sala de crescimento e um telado.

\begin{tabular}{|l|l|l|}
\hline Componentes & Marca & Especificações \\
\hline Ar Condicionado & Springer & 21000 BTU'S Frio 220V \\
\hline Ar Condicionado & Springer & 21000 BTU'S Quente/Frio \\
\hline Material Elétrico & & Fios, starts \\
\hline Termostato Digital & & $220 \mathrm{~V}$ \\
\hline Mão obra eletricista & & especializado \\
\hline Estante de Ferro & & Com prateleiras, sem lateral \\
\hline Material & & $\begin{array}{l}\text { Cal, tijolo, areia, piso, pedra, ferro, janelas, r } \\
\text { tinta }\end{array}$ \\
\hline Mão-de-obra construção & & Não especializada \\
\hline Telado & & Cobertura plástica e sombrite \\
\hline
\end{tabular}




\section{LISTA DE TABELAS}

TABELA 1 - Dados referentes à temperatura, luminosidade e umidade relativa da sala de crescimento.

\begin{tabular}{cccc}
\hline & $\begin{array}{c}\text { U.R } \\
(\%)\end{array}$ & $\begin{array}{c}\text { Temperatura } \\
\left({ }^{\circ} \mathrm{C}\right)\end{array}$ & $\begin{array}{c}\text { Luminosidade } \\
\left(\mu \mathrm{mol} / \mathrm{m}^{2} / \mathrm{s}\right)\end{array}$ \\
\hline Média & 39,63 & 29,34 & 34,88 \\
Mínimo & 20,2 & 24,26 & 0,25 \\
Máximo & 83,3 & 34,26 & 58,29 \\
\hline
\end{tabular}

TABELA 2 - Dados referentes à temperatura, luminosidade e umidade relativa do telado nas épocas 1,2 e 3.

\begin{tabular}{|c|c|c|c|}
\hline \multicolumn{4}{|c|}{ EPOCA 1} \\
\hline Agosto/98 & $\begin{array}{l}\text { U.R } \\
(\%)\end{array}$ & $\begin{array}{c}\text { Temperatura } \\
\left({ }^{\circ} \mathrm{C}\right)\end{array}$ & $\begin{array}{c}\text { Luminosidade } \\
\left(\mu \mathrm{mol} / \mathrm{m}^{2} / \mathrm{s}\right)\end{array}$ \\
\hline Média & 42,35 & 21,7 & 35,77 \\
\hline Mínimo & 16,60 & 13,89 & 00,00 \\
\hline Máximo & 91,20 & 39,06 & 387,79 \\
\hline \multicolumn{4}{|l|}{ Setembro/98 } \\
\hline Média & 69,62 & 22,58 & 26,37 \\
\hline Mínimo & 15,50 & 10,57 & 00,00 \\
\hline Máximo & 100,00 & 40,60 & 431,57 \\
\hline \multicolumn{4}{|l|}{ Outubro/98 } \\
\hline Média & 72,78 & 23,51 & 31,78 \\
\hline Mínimo & 24,00 & 16,38 & 00,25 \\
\hline Máximo & 98,10 & 39,96 & 341,00 \\
\hline \multicolumn{4}{|l|}{ Novembro/98 } \\
\hline Média & 65,48 & 24,63 & 37,80 \\
\hline Mínimo & 17,90 & 15,00 & 00,25 \\
\hline Máximo & 100,00 & 40,52 & 344,25 \\
\hline
\end{tabular}




\begin{tabular}{|c|c|c|c|}
\hline \multicolumn{4}{|c|}{ ÉPOCA 2} \\
\hline Junho/99 & $\begin{array}{l}\text { U.R } \\
\text { (\%) }\end{array}$ & $\begin{array}{c}\text { Temperatura } \\
\left({ }^{\circ} \mathrm{C}\right)\end{array}$ & $\begin{array}{c}\text { Luminosidade } \\
\left(\mu \mathrm{mol} / \mathrm{m}^{2} / \mathrm{s}\right)\end{array}$ \\
\hline Média & 83,81 & 16,22 & 05,10 \\
\hline Mínimo & 42,20 & 7,11 & 00,00 \\
\hline Máximo & 100,00 & 26,00 & 31,27 \\
\hline \multicolumn{4}{|l|}{ Julho/99 } \\
\hline Média & 77,37 & 19,30 & 05,01 \\
\hline Mínimo & 51,15 & 13,76 & 00,21 \\
\hline Máximo & 95,67 & 26,52 & 30,09 \\
\hline \multicolumn{4}{|l|}{ Agosto/99 } \\
\hline Média & 79,80 & 21,62 & 25,89 \\
\hline Mínimo & 74,00 & 21,62 & 00,00 \\
\hline Máximo & 100,00 & 39,15 & 265,19 \\
\hline \multicolumn{4}{|l|}{ Setembro/99 } \\
\hline Média & 70,34 & 20,65 & 08,62 \\
\hline Mínimo & 19,70 & 10,22 & 00,00 \\
\hline Máximo & 100,00 & 34,34 & 171,12 \\
\hline \multicolumn{4}{|c|}{ ÉPOCA 3} \\
\hline Novembro/99 & $\begin{array}{l}\text { U.R } \\
(\%) \\
\end{array}$ & $\begin{array}{c}\text { Temperatura } \\
\left({ }^{\circ} \mathrm{C}\right)\end{array}$ & $\begin{array}{c}\text { Luminosidade } \\
\left(\mu \mathrm{mol} / \mathrm{m}^{2} / \mathrm{s}\right)\end{array}$ \\
\hline Média & 68,40 & 22,64 & 07,18 \\
\hline Mínimo & 21,20 & 13,46 & 00,00 \\
\hline Máximo & 100,00 & 35,07 & 107,83 \\
\hline \multicolumn{4}{|l|}{ Dezembro/99 } \\
\hline Média & 72,60 & 24,20 & 05,30 \\
\hline Mínimo & 28,30 & 18,50 & 00,00 \\
\hline Máximo & 100,00 & 36,05 & 82,56 \\
\hline \multicolumn{4}{|l|}{ Janeiro/00 } \\
\hline Média & 79,01 & 25,23 & 06,75 \\
\hline Mínimo & 21,70 & 15,90 & 00,00 \\
\hline Máximo & 100,00 & 36,81 & 86,31 \\
\hline \multicolumn{4}{|l|}{ Fevereiro/00 } \\
\hline Média & 84,46 & 24,93 & 08,91 \\
\hline Mínimo & 48,40 & 20,01 & 00,00 \\
\hline Máximo & 100,00 & 34,49 & 135,60 \\
\hline
\end{tabular}


TABELA 3 - Número de brotações na época 1, em três repicagens do cultivar banana Maçã, mantido em condições de sala de crescimento. Época 1 - 21/08/98 a 21/11/98

Banana Maçã - Sala de Crescimento

\begin{tabular}{ccc}
\hline Repicagens & Número de Brotos \\
1 & 26 \\
2 & 50 \\
3 & 101 \\
Total & 177 \\
Média & 4,54 \\
\hline
\end{tabular}

TABELA 4 - Número de brotações na época 1, em três repicagens do cultivar banana Maçã, mantido em condições de telado.

Época 1 - 21/08/98 a 21/11/98

Banana Maçã - Telado

\begin{tabular}{ccc}
\hline Repicagens & Número de Brotos \\
2 & 1 & 8 \\
3 & 25 \\
Total & 42 \\
Média & 85 \\
\end{tabular}


TABELA 5 - Número de brotações na época 1 , em três repicagens do cultivar banana Grande Naine, mantido em condições de sala de crescimento.

Época 1 - 21/08/98 a 21/11/98

Banana Grande Naine - Sala de Crescimento

\begin{tabular}{ccc}
\hline Repicagens & Número de Brotos \\
1 & 2 & 21 \\
3 & 72 \\
Total & 258 \\
Média & 351 \\
\hline
\end{tabular}

TABELA 6 - Número de brotações na época 1, em três repicagens do cultivar banana Grande Naine, mantido em condições de telado.

\begin{tabular}{cc}
\multicolumn{2}{c}{$\begin{array}{c}\text { Época 1 - 21/08/98 a 21/11/98 } \\
\text { Banana Grande Naine - Telado }\end{array}$} \\
\hline Repicagens & Número de Brotos \\
1 & 11 \\
2 & 34 \\
3 & 157 \\
Total & 202 \\
Média & 5,61 \\
\hline
\end{tabular}


TABELA 7 - Número de brotações na época 2, em três repicagens do cultivar banana Maçã, mantido em condições de sala de crescimento.

Época 2 - 25/06/99 a 25/09/99

Banana Maçã - Sala de Crescimento

\begin{tabular}{ccc}
\hline Repicagens & Número de Brotos \\
1 & 15 \\
3 & 49 \\
Total & 42 \\
Média & 106 \\
\hline
\end{tabular}

TABELA 8 - Número de brotações na época 2 , em três repicagens do cultivar banana Maçã, mantido em condições de telado.

\begin{tabular}{|c|c|}
\hline \multicolumn{2}{|c|}{ Época 2 - 25/06/99 a 25/09/99 } \\
\hline \multicolumn{2}{|c|}{ Banana Maçã - Telado } \\
\hline Repicagens & Número de Brotos \\
\hline 1 & 2 \\
\hline 2 & 25 \\
\hline 3 & 44 \\
\hline Total & 71 \\
\hline Média & 1,82 \\
\hline
\end{tabular}


TABELA 9 - Número de brotações na época 2, em três repicagens do cultivar banana Grande Naine, mantido em condições de sala de crescimento.

$$
\text { Época } 2 \text { - 25/06/99 a 25/09/99 }
$$

Banana Grande Naine - Sala de Crescimento

\begin{tabular}{cc}
\hline Repicagens & Número de Brotos \\
1 & 36 \\
2 & 144 \\
3 & 158 \\
Total & 337 \\
Média & 8,66 \\
\hline
\end{tabular}

TABELA 10 - Número de brotações na época 2, em três repicagens do cultivar banana Grande Naine, mantido em condições de telado.

\begin{tabular}{cc}
\multicolumn{2}{c}{$\begin{array}{c}\text { Época 2 - 25/06/99 a 25/09/99 } \\
\text { Banana Grande Naine - Telado }\end{array}$} \\
\hline Repicagens & 6 \\
1 & 40 \\
2 & 67 \\
3 & 113 \\
Total & 2,89 \\
\hline
\end{tabular}


TABELA 11 - Número de brotações na época 3, em três repicagens do cultivar banana Maçã, mantido em condições de sala de crescimento.

Época 3 - 15/11/99 a 15/02/00

Banana Maçã - Sala de Crescimento

\begin{tabular}{ccc}
\hline Repicagens & Número de Brotos \\
1 & 2 & 7 \\
3 & 9 \\
Total & 39 \\
Média & 54 \\
\hline
\end{tabular}

TABELA 12 - Número de brotações na época 3, em três repicagens do cultivar banana Maçã, mantido em condições de telado.

Época 3 - 15/11/99 a 15/02/00

Banana Maçã - Telado

\begin{tabular}{ccc}
\hline Repicagens & Número de Brotos \\
1 & 5 \\
2 & 5 \\
3 & 16 \\
Total & 26 \\
Média & 0,67 \\
\hline
\end{tabular}


TABELA 13 - Número de brotações na época 3, em três repicagens do cultivar banana Grande Naine, mantido em condições de sala de crescimento.

\begin{tabular}{cc}
\hline \multicolumn{2}{c}{ Época 3 - 15/11/99 a 15/02/00 } \\
Banana Grande Naine - Sala de Crescimento \\
\hline Repicagens & Número de Brotos \\
1 & 14 \\
2 & 63 \\
3 & 125 \\
Total & 211 \\
Média & 5,18 \\
\hline
\end{tabular}

TABELA 14 - Número de brotações na época 3, em três repicagens do cultivar banana Grande Naine, mantido em condições de telado.

\begin{tabular}{cc}
\multicolumn{2}{c}{$\begin{array}{c}\text { Época 3 - 15/11/99 a 15/02/00 } \\
\text { Banana Grande Naine - Telado }\end{array}$} \\
\hline Repicagens & Número de Brotos \\
1 & 33 \\
2 & 118 \\
3 & 155 \\
Total & 3,97 \\
Média & \\
\hline
\end{tabular}


TABELA 15 - Dados referentes aos tipos de Tratamentos: Sala de crescimento (Tratamento 1) e Telado (Tratamento 2); Número de Observações; Média do número de brotos; Desvio padrão e Valores Mínimos e Máximos obtidos, para o cultivar Grande Naine.

\begin{tabular}{cccccc}
\hline Tratamento & $\begin{array}{c}\text { Número } \\
\text { Observações }\end{array}$ & $\begin{array}{c}\text { Média } \mathbf{N}^{\mathbf{}} \\
\text { Brotos }\end{array}$ & $\begin{array}{c}\text { Desvio } \\
\text { Padrão }\end{array}$ & Mínimo & Máximo \\
\hline 1 & 38 & 23,68 & 29,32 & 0,00 & 107,00 \\
2 & 38 & 12,37 & 16,94 & 0,00 & 71,00 \\
\hline
\end{tabular}

TABELA 16 - Dados referentes às três diferentes épocas: Número de Observações; Média do número de brotos; Desvio padrão e Valores Máximos e Mínimos para o cultivar Grande Naine.

\begin{tabular}{cccccc}
\hline Épocas & $\begin{array}{c}\text { Número } \\
\text { Observações }\end{array}$ & $\begin{array}{c}\text { Média } \mathbf{N}^{\mathbf{0}} \\
\text { Brotos }\end{array}$ & $\begin{array}{c}\text { Desvio } \\
\text { Padrão }\end{array}$ & Mínimo & Máximo \\
\hline 1 & 24 & 23,04 & 34,05 & 0,00 & 107,00 \\
2 & 26 & 17,31 & 19,83 & 0,00 & 97,00 \\
3 & 26 & 14,11 & 17,16 & 0,00 & 76,00 \\
\hline
\end{tabular}

TABELA 17 - Estimativa de Parâmetros para o cultivar Grande Naine

\begin{tabular}{cccccccc}
\hline Parâmetro & GL & Estimativa & $\begin{array}{c}\text { Desvio } \\
\text { Padrão }\end{array}$ & \multicolumn{2}{c}{$\begin{array}{c}\text { Limite 5\% } \\
\text { Confiança }\end{array}$} & $\mathbf{x}^{2}$ & Pr> $\mathbf{x}^{2}$ \\
\hline Intercepto & 0 & 0,00 & 0,00 & 0,00 & 0,00 & & \\
Trat 1 & 1 & 2,97 & 0,29 & 2,40 & 3,55 & 102,43 & $<0,0001$ \\
Trat 2 & 1 & 2,32 & 0,27 & 1,79 & 2,85 & 72,43 & $<0,0001$ \\
Época 1 & 1 & 0,45 & 0,35 & $-0,23$ & 1,14 & 1,68 & 0,19 \\
Época 2 & 1 & 0,09 & 0,35 & $-0,59$ & 0,77 & 0,07 & 0,80 \\
Época 3 & 0 & 0,00 & 0,00 & 0,00 & 0,00 & & \\
Dispersão & 1 & 1,46 & 0,24 & 1,06 & 2,02 & & \\
\hline
\end{tabular}

TABELA 18 - Análise Estatística TIPO 3 para o cultivar Grande Naine.

\begin{tabular}{cccc}
\hline Fonte & GL & $\mathbf{x}^{2}$ & Pr $>\mathbf{x}^{2}$ \\
\hline Tratamento & 1 & 4,96 & $0,03^{*}$ \\
Época & 2 & 1,92 & 0,38 \\
\hline
\end{tabular}


TABELA 19 - Tratamentos, Número de Observações, Média do número de brotos, Desvio Padrão e Valores Mínimos e Máximos obtidos para o cultivar Maçã.

\begin{tabular}{cccccc}
\hline Tratamento & $\begin{array}{c}\text { Número } \\
\text { Observacões }\end{array}$ & $\begin{array}{c}\text { Média N }^{\mathbf{\sigma}} \\
\text { Brotos }\end{array}$ & $\begin{array}{c}\text { Desvio } \\
\text { Padrão }\end{array}$ & Mínimo & Máximo \\
\hline 1 & 39 & 8,67 & 13,01 & 0,00 & 58,00 \\
2 & 39 & 4,41 & 5,08 & 0,00 & 31,00 \\
\hline
\end{tabular}

TABELA 20 - Etapas, Número de Observações, Média do número de brotos, Desvio Padrão e Valores Máximos e Mínimos para o cultivar Maçã.

\begin{tabular}{cccccc}
\hline Épocas & $\begin{array}{c}\text { Número } \\
\text { Observações }\end{array}$ & $\begin{array}{c}\text { Média N }^{\mathbf{0}} \\
\text { Brotos }\end{array}$ & $\begin{array}{c}\text { Desvio } \\
\text { Padrão }\end{array}$ & Mínimo & Máximo \\
\hline 1 & 26 & 9,69 & 15,99 & 0,00 & 58,00 \\
2 & 26 & 6,81 & 6,18 & 0,00 & 24,00 \\
3 & 26 & 3,11 & 2,47 & 0,00 & 8,00 \\
\hline
\end{tabular}

TABELA 21 - Estimativa de Parâmetros para o cultivar Maçã

\begin{tabular}{cccccccc}
\hline Parâmetro & GL & Estimativa & $\begin{array}{c}\text { Desvio } \\
\text { Padrão }\end{array}$ & \multicolumn{2}{c}{$\begin{array}{c}\text { Limite 5\% } \\
\text { Confianç }\end{array}$} & $\mathbf{x}^{2}$ & $\mathbf{P r}^{2} \mathbf{x}^{2}$ \\
\hline Intercepto & 0 & 0,00 & 0,00 & 0,00 & 0,00 & & \\
Trat 1 & 1 & 1,41 & 0,30 & 0,82 & 1,99 & 21,82 & $<0,0001$ \\
Trat 2 & 1 & 0,73 & 0,31 & 0,12 & 1,35 & 5,49 & $0,0191^{*}$ \\
Época 1 & 1 & 1,12 & 0,37 & 0,39 & 1,83 & 9,24 & $0,0024^{*}$ \\
Época 2 & 1 & 0,83 & 0,37 & 0,10 & 1,56 & 5,02 & $0,0250^{*}$ \\
Época 3 & 0 & 0,00 & 0,00 & 0,00 & 0,00 & & \\
Dispersão & 1 & 1,53 & 0,30 & 1,03 & 2,23 & & \\
\hline
\end{tabular}

TABELA 22 - Análise Estatística TIPO 3 para o cultivar Maçã

\begin{tabular}{cccc}
\hline Fonte & GL & $\mathbf{x}^{2}$ & Pr $^{2} \mathbf{x}^{2}$ \\
\hline Tratamento & 1 & 4,76 & $0,0292^{*}$ \\
Época & 2 & 8,55 & $0,0139^{*}$ \\
\hline
\end{tabular}


TABELA 23 - Tipos de equipamentos, fornecedores com respectivos Modelo/Marca e preços, usados no laboratório de produção de mudas de banana micropropagadas.

\begin{tabular}{|c|c|c|c|}
\hline Equipamento & Fornecedor & Modelo/Marca & Valor (R\$) \\
\hline Fluxo laminar & Veco & VLFS - 12 vertical $(1,20 \mathrm{~m})$ & $5.800,00$ \\
\hline Autoclave & MPL & AV 75 / Phoenix & $2.150,00$ \\
\hline Bico de Bunsem & Acielab & Metalic (4 bicos) & 52,00 \\
\hline DestiladorTipos de equip & Acielab & $\begin{array}{l}\text { Acielabe/ } 5 \mathrm{~L} / \mathrm{H} \\
\text { AC } 425\end{array}$ & 500,00 \\
\hline Deionizador & Acielab & $\begin{array}{l}\text { DE } 1800 \text { / Permution } \\
50 \mathrm{~L} / \mathrm{H}\end{array}$ & 410,00 \\
\hline Reservatório Água & Acielab & 20 Lts/ Permution & 103,00 \\
\hline Phmetro & MPL & PA $200 /$ Tecnopon & 580,00 \\
\hline Balança Precisão & Marconi & $\begin{array}{l}\text { AL } 500 / \text { Marte } \\
\text { Max - } 500 \text { gr / sensib. } 0,001 \mathrm{~g}\end{array}$ & 1530,00 \\
\hline Balança Analítica & Tecnal & $\begin{array}{l}\text { E 02-140 } \\
\text { Ohaus - Explorer } \\
\text { Max - } 210 \mathrm{gr} / \text { sens- } 0,1 \mathrm{mg}\end{array}$ & $3.610,00$ \\
\hline $\begin{array}{l}\text { Estufa de Secagem e } \\
\text { Esterilização }\end{array}$ & MPL & $\begin{array}{l}\text { Q } 317 \text { - B } 132 \\
\text { Quimis } 40 \times 45 \times 40\end{array}$ & 552,00 \\
\hline Agitador Magnético & MPL & Simaton & 192,00 \\
\hline Geladeira & & Eletrolux & 700,00 \\
\hline Freezer & & Eletrolux & 700,00 \\
\hline \multirow[t]{3}{*}{ Microondas } & & Sharp & 250,00 \\
\hline & MPL & $\begin{array}{l}\text { Proveta } \\
\text { M/Nalgon ( Plástico ) } \\
\text { 100/1000/2000ml ( } 2 \text { de cada ) }\end{array}$ & 12,00 \\
\hline & MPL & $\begin{array}{l}\text { Becker ( } 2 \text { de cada ) } \\
\text { M/Naglon (Plástico ) } \\
\text { 50/100/1000/4000ml }\end{array}$ & 64,00 \\
\hline \multirow[t]{4}{*}{ Vidrarias } & MPL & $\begin{array}{l}\text { Becker ( } 2 \text { pares ) } \\
\text { 3000ml ( vidro )Laborglas }\end{array}$ & 54,00 \\
\hline & Acielab & $\begin{array}{l}\text { Erlenmeyer ( } 2 \text { de cada) } 50 / 125 / \\
500 / 1000 \mathrm{ml}\end{array}$ & 60,00 \\
\hline & Acielab & $\begin{array}{l}\text { Pipeta graduada Vidrolabor } \\
\text { ( } 2 \text { de cada) } 1 / 2 / 5 / 10 / 25 \mathrm{ml}\end{array}$ & 30,00 \\
\hline & Acielab & $\begin{array}{l}\text { Frascos Reagentes Shott } 250 \mathrm{ml} \\
\text { ( } 7 \text { frascos) }\end{array}$ & 70,00 \\
\hline \multirow[t]{2}{*}{ Pinça } & MPL & $\begin{array}{l}\text { Metalic ( } 6 \text { pares ) } \\
15 \mathrm{~cm}\end{array}$ & \\
\hline & & $20 \mathrm{~cm}$ & 84,00 \\
\hline Cabo de bisturi & MPL & Guth ( 2 pares ) & 24,00 \\
\hline Lâmina bisturi & MPL & Paramont $11-23 \mathrm{cxc} / 100$ & 35,00 \\
\hline Bastão de vidro & & (2) & 4,00 \\
\hline Galão para água & & $50 \mathrm{~L}(6)$ & 240,00 \\
\hline Total Geral & & & $17.497,00$ \\
\hline
\end{tabular}


TABELA 24 - Custos de Produtos Químicos para confecção de meios utilizados na multiplicação e enraizamento de mudas micropropagadas de banana Maçã e Grande Naine.

\begin{tabular}{|c|c|c|c|c|}
\hline \multicolumn{5}{|c|}{ MACRONUTRIENTES } \\
\hline & & $\mathrm{US} \$ / 1000 \mathrm{~g}$ & g/l de meio & US\$/1 de meio \\
\hline $\mathrm{NH}_{4} \mathrm{NO}_{3}$ & Ammonium nitrate & 55,00 & 1,650 & 0,0908 \\
\hline $\mathrm{KNO}_{3}$ & Potassium nitrate & 54,40 & 1,900 & 0,1034 \\
\hline $\mathrm{CaCl}_{2} \cdot 2 \mathrm{H}_{2} \mathrm{O}$ & Calcium chloride & 45,60 & 0,044 & 0,0201 \\
\hline $\mathrm{MgSO}_{4} \cdot 7 \mathrm{H}_{2} \mathrm{O}$ & Magnesium sulfate & 40,20 & 0,037 & 0,0149 \\
\hline $\mathrm{KH}_{2} \mathrm{PO}_{4}$ & Potassium phosphate & 67,60 & 0,017 & 0,0115 \\
\hline Total & & & & 0,2407 \\
\hline \multicolumn{5}{|c|}{ MICRONUTRIENTES } \\
\hline & & $\mathrm{US} \$ / 1000 \mathrm{~g}$ & mg / litro & US\$/1 de meio \\
\hline $\mathrm{H}_{3} \mathrm{BO}_{3}$ & Boric acid & 35,20 & 6,200 & 0,00021 \\
\hline $\mathrm{MnSO}_{4} \cdot 4 \mathrm{H}_{2} \mathrm{O}$ & Manganese sulfate & 57,80 & 22,3000 & 0,00128 \\
\hline $\mathrm{ZnSO}_{4} .4 \mathrm{H}_{2} \mathrm{O}$ & Zinc sulfate & 73,40 & 86,000 & 0,00631 \\
\hline $\mathrm{CoCl}_{2} \cdot 6 \mathrm{H}_{2} \mathrm{O}$ & Cobalt chloride & 438,00 & 0,0250 & 0,000011 \\
\hline $\mathrm{CuSO}_{4} .5 \mathrm{H}_{2} \mathrm{O}$ & Cupric sulfate & 59,30 & 0,0250 & 0,000015 \\
\hline $\mathrm{Na}_{2} \mathrm{MoO}_{4} \cdot 2 \mathrm{H}_{2} \mathrm{O}$ & Sodium molybdate & 126,40 & 0,250 & 0,000032 \\
\hline $\mathrm{KI}$ & Potassium iodide & 195,40 & 0,830 & 0,000162 \\
\hline Total & & & & 0,0082 \\
\hline \multicolumn{5}{|c|}{ Fe EDTA } \\
\hline & & US\$ / $1000 \mathrm{~g}$ & $\mathrm{mg} /$ litro & US $\$ / 1$ de meio \\
\hline $\mathrm{Na}_{2}$.EDTA & & 91,60 & 33,600 & 0,0030 \\
\hline $\mathrm{FeSO}_{4} .7 \mathrm{H}_{2} \mathrm{O}$ & & 75,30 & 27,800 & 0,0084 \\
\hline Total & & & & 0,0537 \\
\hline \multicolumn{5}{|c|}{ Vitamina Morel } \\
\hline Tiamina & & 362,00 & 1,00 & 0,00036 \\
\hline Pantotenato de $\mathrm{Ca}$ & & $1.556,67$ & 1,00 & 0,00157 \\
\hline Ácido Nicotínico & & 54,40 & 1,00 & 0,0000544 \\
\hline Piridoxina & & 880,00 & 1,00 & 0,00088 \\
\hline Biotina & & $53.100,00$ & 0,01 & 0,000531 \\
\hline \multirow{3}{*}{$\mathrm{C}_{12} \mathrm{H}_{22} \mathrm{O}_{11}$} & & $\mathrm{US} \$ / 1000 \mathrm{~g}$ & g/litro & US $\$ / 1$ de meio \\
\hline & Sucrose & 43,30 & 45,00 & 1,9500 \\
\hline & Phytagel & 169,60 & 4,00 & 0,3400 \\
\hline Hormônio BAP & & $25.200,00$ & 4,50 & 0,11 \\
\hline Preço por litro em & \$ para multiplicação & & & 2,68 \\
\hline Preço por litro em & \$ para enraizamento & & & 2,57 \\
\hline
\end{tabular}


TABELA 25 - Custos com energia elétrica utilizada na micropropagação de mudas de banana Maçã e Grande Naine em sala de crescimento.

\begin{tabular}{|c|c|c|c|c|c|c|c|}
\hline Componentes & Qtdd & $\mathrm{KW} / \mathrm{h}$ & $\begin{array}{l}\text { Horas } \\
\text { funciona/o }\end{array}$ & $\begin{array}{l}\text { Total } \\
\mathrm{KW} / \text { dia }\end{array}$ & $\begin{array}{l}\text { Total } \\
\text { KW/mês }\end{array}$ & $\begin{array}{l}\text { Preço } \\
\text { KW/hora }\end{array}$ & $\begin{array}{l}\text { Preço/mês } \\
\text { em R\$ }\end{array}$ \\
\hline $\begin{array}{l}\mathrm{Ar} \\
\text { condicionado }\end{array}$ & 2 & 3,98 & 10 & 39,8 & 1.194 & 0,19067 & 227,66 \\
\hline Lâmpadas & 220 & 6,6 & 16 & 105,6 & 3.168 & 0,19067 & 604,04 \\
\hline \multicolumn{7}{|c|}{ Preço em $\mathrm{R} \$$ com gasto de energia/mês em sala de crescimento } & 831,70 \\
\hline
\end{tabular}

TABELA 26 - Custos de energia elétrica em forno de microondas e na autoclave, utilizados na preparação de meios de cultura em sala de crescimento e em telado.

\begin{tabular}{llrrrr}
\hline Componentes & $\begin{array}{c}\text { Consumo } \\
\text { KW/h }\end{array}$ & $\begin{array}{c}\text { Tempo de } \\
\text { Uso }\end{array}$ & $\begin{array}{c}\text { Consumo } \\
\text { KW/l }\end{array}$ & $\begin{array}{c}\text { Preço KW } \\
\text { em R\$ }\end{array}$ & Preço/l R\$ \\
\hline Microondas & 1,45 & 10 minutos & 0,145 & 0,19067 & 0,028 \\
Autoclave & 4,00 & 55 minutos & 3,670 & 0,19067 & 0,700 \\
Total & & & & & 0,728 \\
\hline
\end{tabular}

TABELA 27 - Custo final de mudas (R\$) micropropagadas de banana Maçã e Grande Naine, produzidas em sala de crescimento e em telado nas três épocas da realização do experimento.

\begin{tabular}{|c|c|c|c|c|}
\hline \multirow[t]{2}{*}{ Item } & \multicolumn{2}{|c|}{ Sala Crescimento } & \multicolumn{2}{|c|}{ Telado } \\
\hline & GN & Maçã & GN & Maçã \\
\hline Litros de meio para multiplicação & 20,35 & 12,55 & 14,10 & 11,50 \\
\hline Preço/l de meio multiplicação & 1,34 & 1,34 & 1,34 & 1,34 \\
\hline 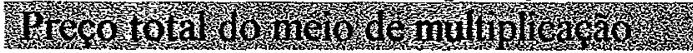 & 2122 & 16 & 188 & 1 \\
\hline Litros de meio para enraizamento & 9,00 & 3,40 & 4,70 & 1,82 \\
\hline Preço/l de meio enraizamento & 1,29 & 1,29 & 1,29 & 1,29 \\
\hline 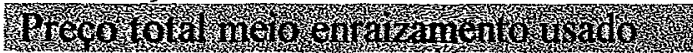 & 1116 & (3) & 606 & 28 \\
\hline Gasto com energia: produção de mudas & 242,16 & 242,16 & 2,91 & 2,91 \\
\hline Número total de mudas produzidas & 900 & 337 & 470 & 182 \\
\hline Preço final por muda & 0,312 & 0,781 & 0,059 & 0,114 \\
\hline
\end{tabular}

* Para as transformações dos custos dos preços por litro dos meios (Tabela 25) para

Reais, adotou-se a taxa cambial de 1,00 US $\$=2,00 \mathrm{R} \$$ 
TABELA 28 - Custo em reais de implementação de sala de crescimento de $8 \mathrm{~m}^{2}$ utilizada na micropropagação de mudas de banana Maçã e Grande Naine.

\begin{tabular}{lll}
\hline \multicolumn{1}{c}{ Item } & \multicolumn{1}{c}{ Especificação } & \multicolumn{1}{c}{ Custo (R\$) } \\
\hline Ap. ar condicionado & 21000 BTU'S Frio 220 & $1.480,00$ \\
Ap. ar condicionado & 21000 BTU'S Quente/Frio 220 & $1.480,00$ \\
Material elétrico & Vários & $3.784,00$ \\
Termostato digital & 220V & 90,00 \\
Mão de obra eletricista & & $3.000,00$ \\
Estante de ferro & 8 unidades: R\$ 80,00 cada & 640,00 \\
Materiais de construção & Cal, cimento, areia, pisos etc... & $8.000,00$ \\
Mão de obra pedreiro & & $5.000,00$ \\
Custo total para $8 \mathrm{~m}^{2}$ & & $23.939,00$ \\
Custo por $\mathrm{m}^{2}$ & & $2.992,38$ \\
\hline
\end{tabular}

TABELA 29 - Custo de implementação de telado utilizado na micropropagação de mudas de banana Maçã e Grande Naine.

\begin{tabular}{ccc}
\hline Área do telado $\left(\mathrm{m}^{2}\right)$ & Custo da mão de obra $\left(\mathrm{m}^{2}\right)$ & Custo total $(\mathrm{R} \$)$ \\
\hline 12 & 30,00 & 360,00 \\
\hline
\end{tabular}

